\title{
Bibliography
}

Akyeampong, Emmanuel K. Drink, Power and Cultural Change. Social History of Alcohol in Ghana, c. 1800 to Recent Times. Portsmouth: James Currey, 1996.

Akyeampong, Emmanuel K. “'Wo pe tam won pe ba.' Urbanization, Individualism \& Gender Relation in Colonial Ghana." In Africa's Urban Past, edited by David Anderson and Richard Rathbone, 222-234. Portsmouth: James Currey, 2000.

Akyeampong, Emmanuel K., and Charles Ambler. "Leisure in African History: An Introduction." International Journal of African History Studies 35, no. 1 (2002): 1-16.

Albertini, Rudolf von. Dekolonisation. Die Diskussion über Verwaltung und Zukunft der Kolonien 1919-1960. Cologne: Westdeutscher Verlag, 1966.

Alegi, Peter. African Soccerscapes: How a Continent Changes the World's Game. Athens: Ohio University Press, 2010.

Allmann, Jean, ed. Fashioning Africa. Power and the Politics of Dress. Bloomington: Indiana University Press, 2004.

Allman, Jean. "Phantoms of the Archive: Kwame Nkrumah, a Nazi Pilot Named Hanna, and the Contingencies of Postcolonial History-Writing." American Historical Review 118, no. 1 (2013): $104-129$.

Ambler, Charles. "Alcohol, Racial Segregation and Popular Politics in Northern Rhodesia." Journal of African History 31 (1990) no. 2: 295-313.

Ambler, Charles. "Mass Media and Leisure in Africa." The International Journal of African Historical Studies 35 (2002): 119-135.

Anderson, Benedict. Imagined Communities. Reflections on the Origin and Spread of Nationalism. London: Verso, 1991.

Anderson, Carol. Bourgeois Radicals. The NAACP and the Struggle for Colonial Liberation 1941-1960. Cambridge: Cambridge University Press, 2014.

Anderson, David, and Richard Rathbone. "Urban Africa. Histories in the Making." In Africa's Urban Past, edited by David Anderson and Richard Rathbone, 1-18. Portsmouth: James Currey, 2000.

Anignikin, Sylvain. “Les élites africaines et l'indépendance. Le cas des 'évolués' du Dahomey (Benin)." Outre-mers, Revue d'histoire 98 (2010): 368-369.

Anstey, Robert. "Belgian Rule in the Congo and the Aspirations of the 'Évolué' Class." In Colonialism in Africa 1870-1960, vol. 2, edited by Peter Duignan and Lewis H. Gann, 194-225. Cambridge: Cambridge University Press, 1970.

Artigue, Pierre. Qui sont les leaders africains, Brussels: Editions Europe-Afrique, 1961.

Austen, Ralph A., and Jonathan Derrick. Middlemen of the Cameroons Rivers. The Duala and their Hinterland, 1600-1960. Cambridge: Cambridge University Press, 1999.

Baberowski, Jörg. "Was sind Repräsentationen sozialer Ordnungen im Wandel? Anmerkungen zu einer Geschichte interkultureller Begegnungen.” In Arbeit an der Geschichte: Wie viel Theorie braucht die Geschichtswissenschaft?, edited by Jörg Baberowski, 7-18. Frankfurt am Main: Campus, 2010.

Bakajika, Thomas B. Partis et société civile au Congo-Zaïre. La démocratie en crise: 1956-1965 \& 1990-1997. Paris: L’Harmattan, 2004.

Balandier, Georges. "La situation coloniale: Approche théoretique." Cahiers Internationaux de Sociologie 11 (1951): $44-79$.

Balandier, Georges. Sociologie des Brazzavilles noires. Paris: Presses de Sciences Po, 1955.

Ә OpenAccess. (C) 2021 Daniel Tödt, published by De Gruyter. (cc) BY Creative Commons Attribution 4.0 International License. https://doi.org/10.1515/9783110709308-015 
Baller, Susann. Spielfelder der Stadt. Fußball und Jugendpolitik im Senegal seit 1950.

Cologne: Böhlau, 2010.

Bandeira Jerónimo, Miguel. “Restoring Order, Inducing Change: Imagining a 'New (Woman)' in the Belgian Colonial Empire in the 1950s." Comparativ 28, no. 5 (2018): $77-96$. https:// doi.org/10.26014/j.comp.2018.05.05.

Bandeira Jéronimo, Miguel. The "Civilising Mission" of Portuguese Colonialism, 1870-1930. London: Palgrave Macmillan, 2015.

Bandeira Jéronimo, Miguel, and António Costa Pinto. "A Modernising Empire? Politics, Culture, and Economy in Portuguese Late Colonialism." In The Ends of European Colonial Empires. Cases and Comparisons, edited by Miguel Bandeira Jéronimo and António Costa Pinto, 51-80. London: Palgrave Macmillan, 2015.

Banerjee, Sukanya. Becoming Imperial Citizens: Indians in the Late-Victorian Empire. Durham: Duke University Press, 2010.

Banti, Alberto Mario. “Der Verein.” In Orte des Alltags. Miniaturen aus der europäischen Kulturgeschichte, edited by Heinz-Gerhard Haupt, 105-110. Munich: C.H. Beck, 1994.

Barth, Boris, and Jürgen Osterhammel, eds. Zivilisierungsmissionen. Imperiale Weltverbesserung seit dem 18. Jahrhundert. Konstanz: UVK, 2005.

Bausinger, Hermann. "Bürgerlichkeit und Kultur.” In Bürger und Bürgerlichkeit im 19. Jahrhundert, edited by Jürgen Kocka, 121-142. Göttingen: Vandenhoeck \& Ruprecht, 1987.

Bavuidinsi Matondo, Andoche. Le système scolaire au Congo-Kinshasa. De la centralisation bureaucratique à l'autonomie des services. Paris: L'Harmattan, 2012.

Beeckmans, Luce, and Johan Lagae. "Kinshasa's Syndrome-Planning in Historical Perspective: from Belgian Colonial Capital to Self-Constructed Megalopolis." In Urban Planning in Sub-Saharan Africa: Colonial and Post-Colonial Planning Cultures, edited by Carlos Nunes Silva, 201-224. London: Routledge, 2015.

Beghin, Ivan. “Joseph Van Riel.” In Biographie Belge d'Outre-Mer, vol. 9, edited by Académie Royale des Sciences d’Outre-Mer, col. 403-405. Brussels: Librairie Falk fils, 2015.

Behler, Ernst. Unendliche Perfektibilität. Europäische Romantik und Französische Revolution. Paderborn: Ferdinand Schöningh, 1989.

Behrends, Andreas, and Julia Pauli. "Zwischen Charisma und Korruption. Kontinuitäten und Brüche in der Auseinandersetzung mit Eliten in Afrika." In Kontinuitäten und Brüche. Fünfzig Jahre Unabhängigkeit in Afrika, edited by Thomas Bierschenk and Eva Spiess, 301-320. Cologne: Rüdiger Köppe, 2012.

Bender, Gerald J. Angola Under the Portuguese: The Myth and the Reality. Berkeley: University of California Press, 1978.

Berlage, Jean. Répertoire de la presse au Congo belge (1884-1954) et du Ruanda-Urundi (1930-1954). Brussels: Commission belge de bibliographie, 1955.

Bernault, Florence. Démocraties ambiguës en Afrique centrale: Congo-Brazzaville, Gabon, 1940-1965. Paris: Karthala, 1996.

Bhabha, Homi. The Location of Culture. London: Routledge, 1994.

Bitsch, Marie-Thérèse. Histoire de la Belgique: De l'Antiquité à nos jours. Brussels: Editions Complexe, 2004.

Blanchard, Pascal, Sandrine Lemaire, Nicolas Bancel, and Dominic Thomas, eds. Colonial Culture in France since the Revolution. Bloomington: Indiana University Press, 2014. 
Bock, Gisela. Geschlechtergeschichten der Neuzeit: Ideen, Politik, Praxis. Göttingen:

Vandenhoeck \& Ruprecht, 2014.

Boelaert, Edmond. “L'Histoire de l'Immatriculation.” Aequatoria 14 (1951): 6-12.

Böhm, Andrea. Gott und die Krokodile. Eine Reise durch den Kongo. Munich: Pantheon, 2011.

Bolamba, Antoine-Roger. Les problèmes de l'évolution de la femme noire. Elisabethville: Éditions de l'Essor du Congo, 1949.

Bolamba, Antoine-Roger, and Christophe Cassiau-Haurie. Carnets de voyage. Congo-Belgique 1945-1959. Paris: L'Harmattan, 2009.

Bontinck, François. "Les missions catholiques à Léopoldville durant la seconde guerre mondiale." In Le Congo belge durant la seconde guerre mondiale, edited by Académie royale, 399-418. Brussels: 1983.

Borutta, Manuel. "Religion und Zivilgesellschaft: Zur Theorie und Geschichte ihrer Beziehung." WZB Discussion Paper 4 (2005).

Boukari-Yabara, Amzat. Africa Unite! Une histoire du panafricanisme. Paris: La Découverte, 2014.

Bourdieu, Pierre. Distinction: A Social Critique of the Judgement of Taste. Cambridge: Harvard University Press, 1979.

Bourdieu, Pierre. Raisons pratiques. Sur la théorie de l'action. Paris: Seuil, 1994.

Bourdieu, Pierre. "Site Effects." In The Weight of the World. Social Suffering in Contemporary Society, edited by Pierre Bourdieu, 123-129. Stanford: Stanford University Press, 1993.

Bouwer, Karen. Gender and Decolonization in the Congo. The Legacy of Patrice Lumumba. London: Palgrave Macmillan, 2010.

Boyle, Patrick M. "School Wars. Church, State, and the Death of the Congo." Journal of Modern African Studies 33, no. 3 (1995): 451- 468.

Braeckman, Colette, ed. Congo 1960. Échec d'une décolonisation. Brussels: GRIP, 2010.

Brassinne de la Buissière, Jacques, and Georges-Henri Dumont. "Les autorités belges et la décolonisation du Congo." Courrier hebdomadaire du CRISP 18 (2010): 9-117.

Brassinne, Jacques, and Frédéric Vandewalle. Les rapports secrèts de la sûreté congolaise. Brussels: Éditions Art et Voyages, 1973.

Brausch, Georges. Belgian Administration in the Congo. London: Oxford University Press, 1961.

Budde, Gunilla-Friederike. “Geschlechtergeschichte.” In Geschichtswissenschaften. Eine Einführung, edited by Christoph Cornelißen, 282-294. Frankfurt am Main: Fischer, 2000.

Budde, Gunilla-Friederike, Eckart Conze, and Cornelia Rauh, eds. Bürgertum nach dem bürgerlichen Zeitalter. Leitbilder und Praxis nach 1945. Göttingen: Vandenhoeck \& Ruprecht, 1997.

Burbank, Jane, and Frederick Cooper. Empires in World History. Power and the Politics of Difference. Princeton: Princeton University Press, 2010.

Burlion, J. “J. P. Quix.” In Biographie Belge d’Outre-Mer, vol. 7-B, ed. Académie Royale des Sciences d'Outre-Mer, 136-145. Brussels: Librairie Falk fils, 1977.

Busia, Kofi Abrefa. "The Present Situation and Aspirations of Elites in the Gold Coast." International Social Science Bulletin 8, no. 3 (1956) : 424-431.

Bussemer, Thymian. "Propaganda. Theoretisches Konzept und geschichtliche Bedeutung." Docupedia-Zeitgeschichte. Accessed February 4, 2021. doi.org/10.14765/zzf.dok.2.239.v1. 
Camilleri, Nicola. "Colonial Subjects and Others: Racism and Inequality during Italian Rule in the Horn of Africa." Northeast African Studies 20, no. 1-2 (2020): 27-58.

Capelle, Emmanuel. La Cité Indigène. Elisabethville: C.E.P.S.I., 1947.

Carlier, Omar. Images du Maghreb, Images au Maghreb. Paris: L'Harmattan, 2010.

Centre de Recherche et d'Information Socio-Politiques. "La presse quotidienne au Congo." Courrier hebdomadaire du CRISP 26 (1959): 1-12.

Chakrabarty, Dipesh. Provincializing Europe. Postcolonial Thought and Historical Difference. Princeton: Princeton University Press, 2001.

Chakrabarty, Dipesh. "The Difference - Defferral of a Colonial modernity. Public Debates on Domesticity in British Bengal." In Tensions of Empire. Colonial Cultures in a Bourgeois World, edited by Frederick Cooper and Ann Laura Stoler, 373-405. Berkeley: University of California Press, 1997.

Chamberlaine, Muriel Evelyn. The Scramble for Africa. London: Routledge, 1974.

Chemain-Degrange, Arlette, and Roger Chemain. Panorama critique de la littérature congolaise contemporaine. Paris: Editions Présence Africaine, 2000.

Chomentowski, Gabrielle, and Leyris Thomas. "Médias et décolonisations en Afrique francophone. Une histoire à écrire." Revue d'Histoire Contemporaine de l'Afrique 1 (2021): 1-15.

Claessens, Hubert. La Presse d'Information en Afrique Belge, Louvain: Université Catholique de Louvain, 1958.

Codell, Julie F. "Introduction. Imperial Co-Histories and the British and Colonial Press." In Imperial Co-Histories. National Identities and the British and Colonial Press, edited by Julie F. Codell, 15-26. Madison: Fairleigh Dickinson University Press, 2003.

Cohen, Abner. The Politics of Elite Culture. Berkeley: University of California Press, 1981.

Comaroff, John L. "Colonialism, Culture and the Law: A Foreword." Law and Social Inquiry 26, no. 2 (2006): 305-314.

Comaroff, Jean, and John L. Ethnography and Historical Imagination. Boulder: Westview Press, 1993.

Comaroff, Jean, and John L. Comaroff. "Home-Made Hegemony: Modernity, Domesticity, and Colonialism in South Africa." In African Encounters with Domesticity, edited by Karen Tranberg Hansen, 37-74. New Brunswick: Rutgers University Press, 1991.

Comaroff, Jean, and John L. Of Revelation and Revolution. The Dialectics of Modernity on a South African Frontier, vol. 2. Chicago: University of Chicago Press, 1997.

Coméliau, Jean. L'Évolué. Leverville: Bibliothèque de l'étoile, 1945.

Conklin, Alice L. A Mission to Civilize. The Republican Idea of Empire in France and West Africa, 1895-1930. Stanford: Stanford University Press, 1997.

Connell, R.W., and James W. Messerschmidt. "Hegemonic Masculinity: Rethinking the Concept.” Gender \& Society 19, no.2 (2005): 829-859.

Conrad, Sebastian. "A Cultural History of Global Transformation." In An Emerging Modern World: 1750-1870, edited by Sebastian Conrad and Jürgen Osterhammel, 413-662. Cambridge: Harvard University Press, 2018.

Conrad, Sebastian. Deutsche Kolonialgeschichte. Munich: C. H. Beck, 2008.

Conrad, Sebastian. "Enlightenment in Global History: A Historiographical Critique." American Historical Review 117, no. 4 (2012): 999-1027.

Conrad, Sebastian. Globalgeschichte. Eine Einführung. Munich: C. H. Beck, 2013. 
Conrad, Sebastian. Globalisierung und Nation im Deutschen Kaiserreich. Munich: C. H. Beck, 2006.

Conrad, Sebastian, and Andreas Eckert. "Globalgeschichte, Globalisierung, multiple Modernen: Zur Geschichtsschreibung der modernen Welt.” In Globalgeschichte. Theorien, Ansätze, Themen, edited by Sebastian Conrad, Andreas Eckert, and Ulrike Freitag, 7-52. Frankfurt am Main: Campus, 2007.

Conway, Martin. "Belgium." In Political Catholicism in Europe, 1918-1965, edited by Tom Buchanan and Martin Conway, 187-218. Oxford: Oxford University Press, 1996.

Conway, Martin. Introduction to Political Catholicism in Europe, 1918-1965, edited by Tom Buchanan and Martin Conway, 1-33. Oxford: Oxford University Press, 1996.

Conway, Martin. The Sorrows of Belgium. Liberation and Political Reconstruction, 1944-1947. Oxford: Oxford University Press, 2012.

Conze, Eckart. "Eine bürgerliche Republik?" Geschichte und Gesellschaft 30, no. 3 (2004): 527-542.

Cook, Bernard A. Belgium: A History. New York: Peter Lang, 2002.

Cooper, Frederick. Africa since 1940. The Past of the Present. Cambridge: Cambridge University Press, 2002.

Cooper, Frederick. Citizenship between Empire and Nation. Remaking France and French Africa, 1945-1960. Princeton: Princeton University Press, 2014.

Cooper, Frederick. Colonialism in Question. Theory, Knowledge, History. Berkeley: University of California Press, 2005.

Cooper, Frederick. Decolonization and African Society. The Labor Question in French and British Africa. Cambridge: Cambridge University Press, 1996.

Cooper, Frederick. "From Imperial Inclusion to Republican Exclusion? France's Ambiguous Postwar Trajectory." In Frenchness and the African Diaspora. Identity and Uprising in Contemporary France, edited by Charles Tshimanga, Didier Gondola, and Peter J. Bloom, 91-119. Bloomington: Indiana University Press, 2009.

Cooper, Frederick. Kolonialismus denken, Konzepte und Theorien in kritischer Perspektive. Frankfurt am Main: Campus, 2012.

Cooper, Frederick. "Reconstructing Empire in British and French Africa." Past \& Present 210, no. 6 (2011): $196-210$.

Cooper, Frederick, and Randall M. Packard. Introduction to International Development and the Social Sciences. Essays on the History and Politics of Knowledge, edited by Frederick Cooper and Randall M. Packard, 1-39. Berkeley: University of California Press, 1997.

Cooper, Frederick, and Ann Laura Stoler. "Between Metropole and Colony. Rethinking a Research Agenda." In Tensions of Empire. Colonial Cultures in a Bourgeois World, edited by Frederick Cooper and Ann Laura Stoler, 1-56. Berkeley: University of California Press, 1997.

Cooper, Frederick, and Ann Laura Stoler, eds. Tensions of Empire. Colonial Cultures in a Bourgeois World. Berkeley: University of California Press, 1997.

Coppieters, E. "De Verering van Tata Raphael: Pater de la Kethulle de Ryhove (1890-1956)." Bulletin des Séances 13, no. 3 (1967): 344-361.

Cornet, Anne, and Florence Gillet. Congo-Belgique, 1955-1965. Entre propagande et réalité. Brussels: Renaissance du Livre, 2010.

Couzens, Tim. "Moralizing Leisure Time. The Transatlantic Connection and Black Johannesburg 1918-1936." In Industrialisation and Social Change in South Africa, 
edited by Shula Marks and Richard Rathbone, 314-447. London: Edison-Wesley Longman 1982.

Crèvecoeur, Guibert. Journal d'un commis de l'État au Congo belge: D'après les mémoires de Marc-Armand Crèvecoeur. Paris: L'Harmattan, 2011.

Crowder, Michael. "The Second World War: Prelude to Decolonisation in Africa." In The Cambridge History of Africa, vol. 8 c, 1940-1975, edited by Michael Crowder, 8-51. Cambridge: Cambridge University Press, 1984.

Cuyvers, J.-B. “Auguste Buisseret." In Biographie Belge d'Outre-Mer, vol. 6, edited by Académie Royale des Sciences d'Outre-Mer, col. 136-145. Brussels: Librairie Falk fils, 1968.

Darwin, John. "Decolonization and the End of Empire." In The Oxford History of the British Empire, vol. 5: Historiography, edited by Robin Winks, 541-557. Oxford: Oxford University Press, 1999.

Davidson, Basil. The Black Man's Burden. Africa and the Curse of the Nation-State. London: James Currey, 1992.

De Backer, M. C. Note pour servir à l'étude des 'groupements politiques' à Léopoldville. Brussels: Office de l'information et des relations publiques pour le Congo, 1959.

De Boeck, Filip, and Marie-Françoise Plissard. Kinshasa: Tales of the Invisible City. Leuven: Leuven University Press, 2004.

De Demeulder, Bruno. “OCA (Office des cités africaines, 1952-1960).” In ArchiAfrika Conference Proceedings: Modern Architecture in East Africa around Independence, 141-148. Dar es Salaam: 2005.

De Groof, Matthias. "The Iconography of Patrice Emery Lumumba." In Lumumba in the Arts, edited by Matthias de Groof, 6-23. Leuven: Leuven University Press, 2020.

Dejung, Cristof. "Auf dem Weg zu einer globalen Sozialgeschichte? Neuere Ansätze zu einer Globalgeschichte des Bürgertums." Neue Politische Literatur. Berichte über das internationale Schrifttum 59 (2004): 229-253.

Dejung, Christof. Fäden des globalen Marktes. Eine Sozial- und Kulturgeschichte des Welthandels am Beispiel der Handelsfirma Gebrüder Volkart 1851-1999. Cologne: Böhlau, 2013.

Dejung, Christof. "From Global Civilizing Missions to Racial Warfare: Class Conflicts and the Representation of the Colonial World in European Middles Class Thought." In The Global Bourgeoisie. The Rise of the Middle Classes in the Age of Empire, edited by Christof Dejung, David Motadel, and Jürgen Osterhammel, 251-271. Princeton: Princeton University Press, 2019.

Dejung, Christof. "Transregional Study of Class, Social Groups, and Milieus." In The Routledge Handbook of Transregional Studies, edited by Matthias Middell, 74-81. New York: Routledge, 2019.

Dejung, Christof, David Motadel, and Jürgen Osterhammel, eds. The Global Bourgeoisie. The Rise of the Middle Classes in the Age of Empire. Princeton: Princeton University Press, 2019.

Dejung, Christof, David Motadel, and Jürgen Osterhammel. "Worlds of the Bourgeoisie." In The Global Bourgeoisie. The Rise of the Middle Classes in the Age of Empire, edited by Christof Dejung, David Motadel, and Jürgen Osterhammel, 1-39. Princeton: Princeton University Press, 2019. 
Dejung, Christof, and Martin Langwiler, eds. "Einleitung." In Ränder der Moderne. Neue Perspektiven auf die Europäische Geschichte (1800-1930), edited by Christof Dejung and Martin Langwiler, 7-35. Cologne: Böhlau, 2016.

Delwit, Pascal, and Benoît Hellings. "Du parti catholique au Centre démocrate humaniste. Les questionnements de la démocratie chrétienne en Belgique francophone." In L'année sociale 2002, edited by Sophie Béroud, 13-31. Brussels: Éditions Syllepse, 2003.

Denis, J. “J. Van Wing.” In Biographie Belge d'Outre-Mer, vol. VIII, edited by Académie Royale des Sciences d'Outre-Mer, col. 461-470. Brussels: Librairie Falk fils, 1998.

Deny, Georges A. "Éditeur de Lomani Tchibamba et de naigiziki. Témoignage recueilli par Emile van Balberghe." In Papier blanc, encre noire. Cent ans de culture francophone en Afrique centrale (Zaïre, Rwanda, Burundi), edited by Marc Quaghebeur and Emile Van Balberghe, 293-300. Brussels: Labor, 1992.

Depaepe, Marc. "Sous le signe du paternalisme: les politiques éducatives au Congo belge, 1908-1960." In L'école et la nation, edited by Benoît Falaize, Charles Heimberg, Olivier Loubes, 435-442. Lyon: ENS Éditions, 2010.

Depaepe, Marc, and Karen Hulstaert. "Creating Cultural Hybridity by Exporting Metropolitan Structures and Cultures of Schooling and Educationalisation? The Emergence of a Congolese 'Elite' in the 1950s as a Starting Point for Further Research." European Educational Research Journal 12, no. 2 (2013): 201-214.

Depaepe, Marc, and Karen Hulstaert. "Demythologising the Educational Past: An Attempt to Assess the Power of Education in the Congo (DRC) with a Nod to the History of Interwar Pedagogy in Catholic Flanders." Paedagogica Historica 51 (2015): 11-29.

Derkinderen, Gaston. “Oscar Defawe.” In Biographie Belge d'Outre-Mer, vol. 7-A, edited by Académie Royale des Sciences d'Outre-Mer, col. 163-165. Brussels: Librairie Falk fils, 1973.

De Schrevel, Michel. Les forces politiques de la décolonisation congolaise jusqu'à la veille de l'indépendance. Louvain: Impr. M. \& L. Symons, 1970.

Deslaurier, Christine. "Du nouveau pour l'histoire politique au Burundi à la veille de l'indépendance. La documentation secrète de la Sûreté (1958-1961)." Cahiers du CRA 9 (1998): 39-69.

De Witte, Ludo. The Assassination of Lumumba. New York: Verso, 2011.

Dibwe dia Mwenbu, Donatien. "La formation des élites coloniales. Le cas de la province Katanga.” In Le manifeste ,Conscience africaine“ (1956). Élites congolaises et sociétés coloniales. Regards croisées, edited by Nathalie Tousignant, 117-139. Brussels: Presses de l'Université Saint-Louis, 2009.

Domont, Jean-Marie. D'homme à homme/Van mens tot mens. Léopoldville: Service de l'information du Gouvernement général du Conge Belge, 1955.

Domont, Jean-Marie. Élite noire. Brussels: Office de Publicité, 1948.

Dorman, Sara Rich. "Citizenship in Africa: The Politics of Belonging." In Routledge Handbook of Global Citizenship Studies, edited by Engin F. Isin and Peter Nyers, 161-171. London: Routledge, 2014.

Drayton, Richard. "Race, Culture, and Class: European Hegemony and Global Class Formation, Circa 1800-1950." In The Global Bourgeoisie. The Rise of the Middle Classes in the Age of Empire, edited by Christof Dejung, David Motadel, and Jürgen Osterhammel, 339-358. Princeton: Princeton University Press, 2019. 
Du Bois, W. E. B. “The Talented Tenth.” In The Negro Problem: A Series of Articles by Representative Negroes of Today, edited by Booker T. Washington, 31-77. New York: J. Pott \& Co, 1903.

Dujardin, Vincent, and Michel Dumoulin. L'union fait-elle toujours la force? Brussels: Le Cri, 2008.

Dülffer, Jost, and Marc Frey. Introduction to Elites and Decolonization in the Twentieth Century, edited by Jost Dülffer and Marc Frey, 1-10. Basingstoke: Palgrave, 2011.

Durieux, André. De la liberté de la presse en droit belge colonial. Brussels: Université Libre de Bruxelles, 1958.

Eckert, Andreas. “Afrika in der Welt. Afrikanische Geschichte im 20. Jahrhundert.” In Geschichte denken. Perspektiven auf die Geschichtsschreibung heute, edited by Michael Wildt, 1311-47. Göttingen: Vandenhoeck \& Ruprecht, 2014.

Eckert, Andreas. “Cultural Commuters: African Employees in Late Colonial Tanzania." In Intermediaries, Interpreters, and Clerks. African Employees in the Making of Colonial Africa, edited by Benjamin N. Lawrence, Emily Lynn Osborn, and Richard L. Roberts, 248-269. Wisconsin: University of Wisconsin Press, 2006.

Eckert, Andreas. "Die Verheißung der Bürokratie. Verwaltung als Zivilisierungsagentur im kolonialen Westafrika." In Zivilisierungsmissionen. Imperiale Weltverbesserung seit dem 18. Jahrhundert, edited by Boris Barth and Jürgen Osterhammel, 269-283. Konstanz: UVK, 2005.

Eckert, Andreas. Exportschlager Wohlfahrtsstaat? Europäische Sozialstaatlichkeit und Kolonialismus in Afrika nach dem Zweiten Weltkrieg. Bochum: Stiftung Bibliothek des Ruhrgebiets, 2007.

Eckert, Andreas. Grundbesitz, Landkonflikte und kolonialer Wandel. Douala 1880-1960. Stuttgart: Franz Steiner, 1999.

Eckert, Andreas. Herrschen und Verwalten. Afrikanische Bürokraten, staatliche Ordnung und Politik in Tanzania, 1920-1970. München: Oldenbourg, 2007.

Eckert, Andreas. Kolonialismus. Frankfurt am Main: S. Fischer, 2006.

Eckert, Andreas. “Kolonialismus, Moderne und koloniale Moderne in Afrika." In Selbstbilder und Fremdbilder. Repräsentationen sozialer Ordnungen im Wandel, edited by Jörg Baberowski, Hartmut Kaelble, and Jürgen Schriewer, 53-66. Frankfurt am Main: Campus, 2008.

Eckert, Andreas. "Spätkoloniale Herrschaft, Dekolonisation und internationale Ordnung. Einführende Bemerkungen.” AfS 48 (2008): 3-20.

Eckert, Andreas. “'Unordnung' in den Städten. Stadtplanung, Urbanisierung und koloniale Politik in Afrika." Periplus. Jahrbuch für außereuropäische Geschichte 6 (1996): 1-20.

Eckert, Andreas. “Wohlfahrtsmix, Sozialpolitik und 'Entwicklung' in Afrika im 20. Jahrhundert." In Sozialpolitik in der Peripherie. Entwicklungsmuster und Wandel in Lateinamerika, Afrika, Asien und Osteuropa, edited by Johannes Jäger, Gerhard Melinz, Susan Zimmermann, and G. Melinz, 99-116. Vienna: Südwind, 2001.

Eckert, Andreas, and Adam Jones. "Historical Writing about Everday Life." Journal of African Cultural Studies 15, no. 1 (2002): 5-16.

Enwezor, Okwui. The Short Century: Independence and Liberation Movements in Africa, 1945-1994. Munich: Prestel Verlag, 2001.

Éditions Service de l'Information. Reviens à la vie! L'Élite congolaise contre l'Alcoolisme. Kalina: 1953. 
Ege, Moritz. Ein Proll mit Klasse. Mode, Popkultur und soziale Unterschichten unter jungen Männern in Berlin. Frankfurt am Main: Campus, 2013.

Ege, Moritz. "Zur Performativität von 'wannabees.”' In Orte - Situationen - Atmosphären. Kulturanalytische Skizzen, edited by Beate Binder, Moritz Ege, Anja Schwanhäußer, Jens Wietschorke, 289-306. Frankfurt am Main: Campus, 2010.

Egger, Christine, and Martina Gugglberger. "Editorial.” Österreichische Zeitschrift für Geschichtswissenschaften 24, no. 2 (2013): 5-20.

Ekabmo, Jean-Chrétien. “La Voix du Congolais s'est éteinte.” Le Phare, 21 October 2010, www.lephareonline.net/la-voix-sest-eteinte/ (1 May 2015).

Ekeh, Peter P. "Colonialisms and the Two Publics in Africa: A Theoretical Statement." Comparative Studies in Society and History 17 (1975): 92-112.

Eloko, Nongo Otshudiema. Les structures inconscientes de "La Voix du congolais" (1959). Brussels: CEDAF, 1975.

Esgain, Nicolas. "Scènes de la vie quotidienne à Elisabethville dans les années vingt." In Itinéraires croisés de la modernité Congo belge (1920-1950), edited by Jean-Luc Vellut, 57-70. Paris: L'Harmattan, 2001.

Etzemüller, Thomas. "Social Engineering." Docupedia-Zeitgeschichte. Accessed February 4, 2021. doi:10.14765/zzf.dok.2.1112.v2.

Ewens, Martin. "Belgium and the Colonial Experience." Journal of Contemporary European Studies 11, no. 2 (2003): 167-180.

Fabian, Johannes. "Popular Culture in Africa. Findings and Conjectures." Africa 48 (1978): $315-334$.

Fabian, Johannes. The Time and the Other. How Anthropology Makes its Object. New York: Columbia University Press, 1983.

Faulstich, Werner. Die Kultur der 50er Jahre. Paderborn: Wilhelm Fink, 2002.

FEDACOL. L'opinion publique coloniale devant l'assimilation des indigènes. Brussels: mimeographed, 1951.

Fierens, Marie. "Journalisme et politique en Côte d'Ivoire (années 1930-1964). Itinéraires croisés d'une profession." Revue d'Histoire Contemporaine de l'Afrique 1 (2021): 98-118.

Fierens, Marie. "Reporting on the Independance of Belgian Congo: Mwissa Camus, the Dean of Congolese Journalists." African Journalism Studies 37 (2016): 81-99.

Finsterhölzl, Regina. Kommerzielle Werbung im kolonialen Afrika. Die Werbebranche und der politische Wandel in Ghana 1930-1970. Cologne: Böhlau, 2015.

Finsterhölzl, Regina. "The spirit of true socialism. Das Fabian Colonial Bureau und die koloniale Reformpolitik im subsaharischen Afrika." ZfG 58 (2012): 994-1013.

Fischer-Tiné, Harald, and Susanne Gehrmann. "Introduction: Empire, Boundaries and the Production of Difference." In Empire and Boundaries. Rethinking Race, Class, and Gender in Colonial Settings, edited by Harald Fischer-Tiné and Susanne Gehrmann, 1-22. New York: Routledge, 2009.

Fisher, Josephine Lucy. Pioniers, Settlers, Aliens, Exiles. The Decolonisation of White Identity in Zimbabwe. Canberra: ANU Press, 2010.

Floré, Fredie. "Promoting Catholic Family Values and Modern Domesticity in Postwar Belgium." In Negotiating Domesticity. Spatial Productions of Gender in Modern Architecture, edited by Hilde Heynen and Gülsüm Baydar, 83-102. New York: Routledge, 2005. 
Forde, Daryll. Introduction to Aspects sociaux de l'industrialisation et de l'urbanisation en Afrique au Sud du Sahara, edited by D. Forde, 11-56. Paris: UNESCO, 1956.

Franck, Louis. Le Congo belge. Brussels: La Renaissance du livre, 1930.

Frederiksen, Bodil F. “'The Present Battle is the Brain Battle': Writing and Publishing a Kikuyu Newspaper in the Pre-Mau Mau Period in Kenya." In Africa's Hidden Histories: Everyday Literacy and Making the Self, edited by Karin Barber, 278-313. Bloomington: Indiana University Press, 2006.

Freund, Bill. The African City. A History. Cambridge: Cambridge University Press, 2007.

Frevert, Ute. "Bürgerliche Meisterdenker und das Geschlechterverhältnis: Konzepte, Erfahrungen, Visionen an der Wende vom 18. zum 19. Jahrhundert.” In Bürgerinnen und Bürger. Geschlechterverhältnisse im 19. Jahrhundert, edited by Ute Frevert, 17-48. Göttingen: Vandenhoeck \& Ruprecht, 1988.

Frevert, Ute. Frauen-Geschichte. Zwischen bürgerlicher Verbesserung und neuer Weiblichkeit. Berlin: Suhrkamp, 1986.

Frevert, Ute. "Neue Politikgeschichte. Konzepte und Herausforderungen." In Neue Politikgeschichte: Perspektiven einer historischen Politikforschung, edited by Ute Frevert and Heinz-Gerhard Haupt, 7-26. Frankfurt am Main: Campus, 2005.

Frevert, Ute, and Margrit Pernau. "Europa ist eine Frau: jung und aus Kleinasien. Beitrag zum Themenschwerpunkt “Europäische Geschichte - Geschlechtergeschichte.” Themenportal Europäische Geschichte 2009, www.europa.clio-online.de/essay/id/artikel-3548 (1 July 2016).

Gadzekpo, Audrey. "Gender Discourse and Representational Practices in Gold Coast Newspapers." Jenda: A Journal of Culture and African Women Studies 1, no. 2 (2001): $1-26$.

Gandoulou, Justin-Daniel. Dandies à Bacongo. Paris: L'Harmattan, 1989.

Gann, L. H., and Peter Duignan, eds. The Rulers of German Africa 1884-1914. Stanford: Stanford University Press, 1977.

Gastrow, Claudia. "Housing Middle-Classness: Formality and the Making of Distinction in Luanda." Africa 90, no. 3 (2020): 509-528.

Gemoets, Marc, Johan Lagae, Bernard Toulier, eds. Kinshasa. Architecture et paysage urbains. Paris: Somogy Editions, 2010.

Genova, James E. Colonial Ambivalence, Cultural Authenticity and the Limitations of Mimicry in French-Ruled West Africa, 1914-1956. New York: Peter Lang, 2004.

George, Abosede. Making Modern Girls: A History of Girlhood, Labor, and Social Development in 20th-Century Colonial Lagos. Athens: Ohio University Press, 2014.

George, Betty Stein. Education in Ghana. Washington: ERIC Clearinghouse, 1976.

Gijs, Anne-Sophie. Le pouvoir de l'absent: Les avatars de l'anticommunisme au Congo (1920-1961). Brussels: Peter Lang, 2016.

Gilis, Charles-André. Kasa-Vubu au coeur du drame congolais. Brussels: Editions EuropeAfrique, 1964.

Ginzburg, Carlo. The Cheese and the Worms: The Cosmos of a Sixteenth Century Miller. Baltimore: John Hopkins University Press, 1980.

Glasman, Joël. Les corps habillés au Togo. Genèse des métiers de police. Paris: Karthala, 2015.

Glassman, Jonathon. "Sorting out the Tribes: The Creation of Racial Identities in Colonial Zanzibar's Newspaper.” Journal of African History 41, no. 3 (2000): 395-428. 
Goebel, Michael. Anti-Imperial Metropolis. Interwar Paris and the Seeds of Third World Nationalism. New York: Cambridge University Press, 2015.

Goerg, Odile. Perspectives historiques sur le genre en Afrique. Paris: L'Harmattan, 2007. Gondola, Ch. Didier. "Dream and Drama: The Search for Elegance among Congolese Youth." African Studies Review 42 (1999): 23-48.

Gondola, Ch. Didier. The History of Congo. Westport: Greenwood, 2002.

Gondola, Ch. Didier. Tropical Cowboys. Westerns, Violence, and Masculinity in Kinshasa. Bloomington: Indiana University Press, 2016.

Gondola, Ch. Didier. "Unies pour le meilleur et pour le pire. Femmes africaines et villes coloniale. Une histoire du métissage." Clio. Femmes, Genre, Histoire d'Afrique 6 (1997): 87-104.

Gondola, Ch. Didier. Villes miroirs. Migrations et identités urbaines à Kinshasa et Brazzaville, 1930-1970. Paris: L'Harmattan, 1996.

Gosewinkel, Dieter. Schutz und Freiheit? Staatsbürgerschaft in Europa im 20. und 21. Jahrhundert. Berlin: Suhrkamp, 2016.

Grant, Kevin. "Christian Critics of Empire: Missionaries, Lantern Lectures, and the Congo Reform Campaign in Britain." The Journal of Imperial and Commonwealth History 29, no. 2 (2008): 27-58.

Gries, Rainer. "Zur Ästhetik und Architektur von Propagemen. Überlegungen zu einer Propagandageschichte als Kulturgeschichte." In Kultur der Propaganda, edited by Rainer Gries and Wolfgang Schmale, 9-35. Bochum: Winkler, 2005.

Große Kracht, Klaus. "Missionsland Europa. Katholische Aktion und "missionarische Bewegung' im französischen und deutschen Katholizismus der 1940er Jahre.” Themenportal Europäische Geschichte (2009), http://www.europa.clio-online.de/2009/ Article=384 (24 September 2013).

Gubin, Eliana, and Jean-Pierre Nandrin. La Belgique libérale et bourgeoise (1846-1878). Brussels: Complexe, 2010.

Guebels, Léon. Relation complète des travaux de la Commission permanente pour la protection des indigènes. Gembloux: Duculot, 1951.

Habermas, Rebekka. Frauen und Männer des Bürgertums. Eine Familiengeschichte (1750-1850). Göttingen: Vandenhoeck \& Ruprecht, 2000.

Habermas, Rebekka. Skandal in Togo. Ein Kapitel deutscher Kolonialherrschaft. Frankfurt am Main: S. Fischer, 2016.

Haffner, Pierre. "Une mémoire singulière. Un entretien avec Paul Lomani Tchibamba (1914-1985)." In Papier blanc, encre noire. Cent ans de culture francophone en Afrique centrale (Zaïre, Rwanda et Burundi), edited by Marc Quaghebeur and Emile Balberghe, 301-324. Brussels: Labor, 1992.

Hahn, Hans Peter. "Von der Ethnographie des Wohnzimmers - zur 'Topographie des Zufalls.” In Die Sprache der Dinge. Kulturwissenschaftliche Perspektiven auf die materielle Kultur, edited by Elisabeth Tietmeyer, Claudia Hirschberger, Karoline Noack, and Jane Redlin, 9-22. Münster: Waxmann, 2010.

Hall, Catherine, and Sonya O. Rose, eds. At Home with the Empire. Metropolitan Culture and the Imperial World. Cambridge: Cambridge University Press, 2006.

Hampâté Bâ, Amadou. L'étrange destin de Wangrin. Paris: Union générale d'éditions, 1973. Hannerz, Ulf. Exploring the City. Inquiries Toward an Urban Anthropology. New York: Columbia University Press, 1980. 
Hansen, Karen Tranberg. "Introduction. Domesticity in Africa." In African Encounters with Domesticity, edited by Karen Tranberg Hansen, 1-36. New Brunswick: Rutgers University Press, 1992.

Hansen, Peo, and Stefan Jonsson. Eurafrica. The Untold History of European Integration and Colonialism. London: Bloomsbury, 2015.

Harries, Patrick. "Anthropology." In Missions and Empire, edited by Norman Etherington, 238-260. Oxford: Oxford University Press, 2005.

Hartmann, Michael. Elitesoziologie. Eine Einführung. Frankfurt am Main: Campus, 2004.

Hausen, Karin. "Das Wohnzimmer." In Orte des Alltags. Miniaturen aus der europäischen Kulturgeschichte, edited by Heinz-Gerhard Haupt, 131-141. Munich: C.H. Beck, 1994.

Heerten, Lasse. “Léopold Sédar Senghor als Subjekt der 'Dialektik des Kolonialismus.' Ein Denker Afrikas und die imperiale Metropole." Stichproben. Wiener Zeitschrift für kritische Afrikastudien 15 (2008): 87-116.

Heinze, Robert. “'It recharged our Batteries.' Medien in der Dekolonisierung Afrikas.” Zeitgeschichte Online, June 2010, http://www.zeitgeschichte-online.de/Themen-Heinze06-2010 (20 February 2021).

Henriet, Benoît. Colonial Impotence. Virtue and Violence in a Congolese Concession (1911-1940). Berlin: De Gruyter, 2021.

Hergé. Tintin in the Congo. Brussels: Casterman, 1952.

Hettling, Manfred. Bürgerlichkeit als kulturelles System. Halle: Universität Halle-Wittenberg, 2010.

Hettling, Manfred. "Die persönliche Selbständigkeit. Der archimedische Punkt bürgerlicher Lebensführung." In Der bürgerliche Wertehimmel. Innenansichten des 19. Jahrhunderts, edited by Manfred Hettling and Stefan-Ludwig Hoffmann, 57-77. Göttingen: Vandenhoeck \& Ruprecht, 2000.

Hettling, Manfred. Politische Bürgerlichkeit: der Bürger zwischen Individualität und Vergesellschaftung in Deutschland und in der Schweiz von 1860 bis 1918. Göttingen: Vandenhoeck \& Ruprecht, 1999.

Hettling, Manfred, and Gesine Foljanty-Jost. Formenwandel der Bürgergesellschaft. Japan und Deutschland im Vergleich. Halle: Universität Halle-Wittenberg, 2009.

Hettling, Manfred, and Stefan-Ludwig Hoffmann. "Zur Historisierung bürgerlicher Werte. Eine Einleitung.” In Der bürgerliche Wertehimmel. Innenansichten des 19. Jahrhunderts, edited by Manfred Hettling and Stefan-Ludwig Hoffmann, 7-22. Göttingen: Vandenhoeck \& Ruprecht, 2000.

Heywood, Linda M. Contested Power in Angola, 1840s to the Present. New York: University of Rochester Press, 2000.

Hilpert, Dagmar. Wohlfahrtsstaat der Mittelschichten? Sozialpolitik und gesellschaftlicher Wandel in der Bundesrepublik Deutschland (1949-1975). Göttingen: Vandenhoeck \& Ruprecht, 2012.

Hochschild, Adam. King's Léopold Ghost: A Story of Greed, Terror, and Heroism in Colonial Africa. London: Mariner books, 1998.

Hodgkin, Thomas. Nationalism in Colonial Africa. London: Muller, 1958.

Hoffmann, Stefan-Ludwig. “Colonial Civil Society." De Negentiende Eeuw 32 (2008): 143-147.

Hoffmann, Stefan-Ludwig. Geselligkeit und Demokratie. Vereine und zivile Gesellschaft im transnationalen Vergleich 1750-1914. Göttingen: Vandenhoeck \& Ruprecht, 2003. 
Hölscher, Lucien. "Die Öffentlichkeit begegnet sich selbst. Zur Struktur öffentlichen Redens im 18. Jahrhundert zwischen Diskurs- und Sozialgeschichte.” In Öffentlichkeit im 18. Jahrhundert, edited by Hans-Wolf Jäger, 11-33. Göttingen: Wallstein, 1997.

Hunt, Nancy Rose. A Colonial Lexicon of Birth Ritual, Medicalization, and Mobility in the Congo. Durham: Duke University Press, 1999.

Hunt, Nancy Rose. A Nervous State: Violence, Remedies, and Reverie in Colonial Congo. Durham: Duke University Press, 2016.

Hunt, Nancy Rose. "Domesticity and Colonialism in Belgian Congo. Usumbura's foyer social, 1946-1960." Signs 5 (1990): 447-474.

Hunt, Nancy Rose. "Hommes et femmes, sujets du Congo colonial." In Les mémoires du Congo. Le temps colonial, edited by Jean-Luc Vellut, 51-57. Gent: Éditions Snoeck, 2005.

Hunt, Nancy Rose. "Le Bébé en Brousse. European Women, African Birth Spacing and Colonial Intervention in Breast Feeding in the Belgian Congo." International Journal of African Historical Studies 21 (1998): 401-432.

Hunt, Nancy Rose. "Letter-Writing, Nursing Men and Bicycles in the Belgian Congo. Notes Towards the Social Identity of a Colonial Category." In Paths Toward the Past. African Historical Essays in Honor of Jan Vansina, edited by R. W. Harms, Joseph C. Miller, David S. Newbury, and Michele D. Wagner, 187-210. Atlanta: African Studies Association Press, 1994.

Hunt, Nancy Rose. "Noise over Camouflaged Polygamy. Colonial Morality Taxation, and a Woman-Naming Crisis in Belgian Africa." Journal of African History 32 (1991): 471-494.

Hunt, Nancy Rose. "Rewriting the Soul in a Flemish Congo." Past \& Present 198, no. 1 (2008): $185-215$.

Hunt, Nancy Rose. "Tintin and the Interruptions of Congolese Comics." In Images and Empires. Visuality in Colonial and Postcolonial Africa, edited by Paul S. Landau and Deborah D. Kaspin, 90-123. Berkeley: University of California Press, 2002.

Hunter, Emma. Introduction to Citizenship, Belonging and Political Community in Africa. Dialogues between Past and Present, edited by Emma Hunter, 1-16. Athens: Ohio University Press, 2016.

Hunter, Emma. "Modernity, print media, and the middle classes in Colonial East Africa." In The Global Bourgeoisie. The Rise of the Middle Classes in the Age of Empire, edited by Christof Dejung, David Motadel, and Jürgen Osterhammel, 105-121. Princeton: Princeton University Press, 2019.

Hunter, Emma. "Newspapers as Sources for African History." Oxford Research Encyclopedias African History (2018). Accessed 11 October 2020, doi:10.1093/acrefore/ 9780190277734.013.228.

Hunter, Emma. “'Our common humanity’: print, power, and the colonial press in interwar Tanganyika and French Cameroun." Journal of Global History 7 (2012): 279-301.

Hunter, Emma. Political Thought and the Public Sphere in Tanzania. Freedom, Democracy and Citizenship in the Era of Decolonization. Cambridge: Cambridge University Press, 2015.

Hunter, Emma, and Leslie James. "Introduction: Colonial Spheres and the Worlds of Print." Itinerario 44, no. 2 (2020): 227-242.

Ibhawoh, Bonny. Imperial Justice. Africans in Empire's Court. Oxford: Oxford University Press, 2013. 
Jadot, Jean-Marie. “Stephane Kaoze.” In Biographie Belge d'Outre-Mer, vol. 6, edited by Académie Royale des Sciences d'Outre-Mer, col. 565-566. Brussels: Librairie Falk fils, 1968.

James, Deborah. Money from Nothing. Indebtedness and Aspiration in South Africa. Stanford: Stanford University Press, 2014.

Jaumain, Serge, and Ginette Kurgan van Hentenryk. Aux frontières des classes moyennes: la petite bourgeoisie belge avant 1914. Brussels: Université de Bruxelles, 1992.

Jennings, Eric. La France libre fut africaine. Paris: Perrin, 2014.

Jewsiewicki, Bogumil. “Le Colonat agricole européen au Congo Belge, 1910-1960, problèmes politiques et économique.” Journal of African History 20 (1979): 559-571.

Jewsiewicki, Bogumil. "Residing in Kinshasa. Between Colonial Modernization and Globalization." Research in African Literatures 39, no. 4 (2008): 105-119.

Jewsiewicki, Bogumil. "The Formation of the Political Culture of Ethnicity in the Belgian Congo, 1920-1959." In The Creation of Tribalism in Southern Africa, edited by Leroy Veil, 324-349. Berkeley: Currey University of California Press, 1991.

Jézéquel, Jean-Hervé. “Grammaire de la Distinction Coloniale.” Genèses 69, no. 4 (2007): $4-25$.

Johnson, Dominic. Kongo. Kriege, Korruption und die Kunst des Überlebens. Frankfurt am Main: Brandel und Apsel, 2008.

Joseph-Gabriel, Annette K. Reimagining Liberation. How Black Women transformed Citizenship in the French Empire. Urbane: University of Illinois Press, 2020.

Joshi, Sanjay. The Middle Class in Colonial India. New Delhi: Oxford University Press, 2010. Judt, Tony. A History of Europe since 1945. London: Penguin, 2005.

Juneja, Monica, and Margrit Pernau. "Lost in Translation? Transcending Boundaries in Comparative History." In Comparative and Transnational History. Central European and New Perspectives, edited by Heinz-Gerhard Haupt and Jürgen Kocka, 105-129. New York: Berghahn, 2009.

Kabiena, Dieudonné Tombe. "Réglementation de la presse au congo belge: approche systématique." In Aspect de la culture à l'époque coloniale en Afrique centrale. PresseArchive, edited by Marc Quaghebeur and Bibiane Tshibola Kalengayi, 41-61. Paris: L'Harmattan, 2008.

Kadima-Nzuji, Mukala. "Autour de la Voix du Congolais. Les premiers auteurs zaïrois.” Notre Librairie 87 (1982): 7-22.

Kadima-Nzuji, Mukala. La Littérature Zaïroise de langue française. Paris: Karthala, 1984.

Kadima-Tshimanga, Bajana. "La société sous le vocabulaire. Blancs, Noirs et Évolués dans l'ancien Congo belge (1955-1959).” Mots 5 (1982): 25- 49.

Kalde, Franz. "Diözesane und quasidiözesane Teilkirchen." In Handbuch des katholischen Kirchenrechts, edited by Joseph Listl and Heribert Schmitz, 420-425. Regensburg: Friedrich Pustet, 1999.

Kalulambi Pongo, Martin. “Le manifeste 'Conscience africaine’: genèse, influences et réactions." In Le manifeste ,Conscience africaine“ (1956). Élites congolaises et sociétés coloniales. Regards croisées, edited by Nathalie Tousignant, 59-81. Brussels: Presses de l'Université Saint-Louis, 2009.

Kambayi, Bwatshia. Blancs et noirs face à la décolonisation du Congo belge. Kinshasa: Presses universitaires du Zaïre, 1992.

Kanza, Thomas. Congo, pays de deux évolués. Léopoldville: Actualités Africaines, 1956. 
Kanza, Thomas. Sans rancune. London: Scotland, 1965.

Kanza, Valérie. "Congo, Journal interdit. Philippe Kanza et Mathieu Ekatou ou la genèse d'une presse congolaise libre et indépendante." In Aspect de la culture à l'époque coloniale en Afrique centrale. Presse-Archive, edited by Marc Quaghebeur and Bibiane Tshibola Kalengayi, 149-184. Paris: L'Harmattan, 2008.

Kasa-Vubu, Z. J. M'Poyo. Joseph Kasa-Vubu, mon père: De la naissance d'une conscience nationale à l'indépendance. Brussels: Chabassol, 1985.

Kaschuba, Wolfgang. "Das Einfamilienhaus. Zwischen Traum und Trauma?” archithese 37, no.3 (2007): $18-21$.

Kaschuba, Wolfgang. "Deutsche Bürgerlichkeit nach 1800 - Kultur als symbolische Praxis." In Bürgertum im 19. Jahrhundert, vol. 3, edited by Jürgen Kocka, 92-127. Göttingen: Vandenhoeck \& Ruprecht, 1987.

Keese, Alexander. Ethnicity and the Colonial State. Finding and Representing Group Identification in a Coastal West African and Global Perspective (1850-1960). Leiden: Brill, 2015.

Keese, Alexander. Living with Ambiguity. Integrating an African Elite in French and Portuguese Africa. Stuttgart: Franz Steiner, 2007.

Kimble, David. A Political History of Ghana. The Rise of Gold Coast Nationalism, 1850-1928. Oxford: Clarendon Press, 1963.

Kirk-Greene, Anthony. The Thin White Line: The Size of the Colonial Service in Africa. Oxford: Oxford University Press, 1980.

Ki-Zerbo, Joseph. Histoire de l'Afrique noire. Paris: Librairie Hatier, 1978.

Kocka, Jürgen, ed. Bürgertum im 19. Jahrhundert. Deutschland im europäischen Vergleich; eine Auswahl. Göttingen: Vandenhoeck \& Ruprecht, 1995.

Kocka, Jürgen. "Das europäische Muster und der deutsche Fall.” In Bürgertum im 19. Jahrhundert, Bd. 1, edited by Jürgen Kocka, 9-84. Göttingen: Vandenhoeck \& Ruprecht 1995.

Koselleck, Reinhart. "Erfahrungsraum und Erwartungshorizont. Zwei historische Kategorien.” In Vergangene Zukunft. Zur Semantik geschichtlicher Zeiten, edited by Reinhart Koselleck, 349-375. Frankfurt am Main: Suhrkamp, 1989.

Krings, Ernest. "Robert Godding." In Nouvelle biographie nationale, vol. 9, ed. Académie Royale, 191-198. Brussels: Académie Royale, 2007.

Kroeker, Lena, David O'Kane, and Tabea Scharrer, eds. Middle Classes in Africa. Changing Lives and Conceptual Challenges. London: Palgrave Macmillan, 2018.

Kuhlemann, Frank-Michael. Bürgerlichkeit und Religion. Zur Sozial- und Mentalitätsgeschichte der evangelischen Pfarrer in Baden 1860-1914. Göttingen: Vandenhoeck \& Ruprecht, 2001.

Kuper, Leo. African Bourgeoisie. Race, Class, and Politics in South Africa. Bloomsbury: Yale University Press, 1965.

Kurgan van Hentenryk, Ginette. "Permanence et recompostion des élites." In Les classes sociales en Belgique. Deux siècles d'histoire, edited by Guy Vanthemsche, 401-442. Brussels: CRISP, 2017.

Laak, D. van. “Kolonien als 'Laboratorien der Moderne?” In Das Kaiserreich transnational. Deutschland in der Welt 1871-1914, edited by Sebastian Conrad and Jürgen Osterhammel, 257-279. Göttingen: Vandenhoeck \& Ruprecht, 2004. 
Lafarge Bembika, André. Sur les pas de pionniers bâtisseurs. Centenaire de l'établissement des frères des écoles chrétiennes au Congo 1909-2009. Kinshasa: Frères des Écoles Chrétiennes, 2009.

Lafontaine, Jean S. City Politics. A Study of Léopoldville. Cambridge: Cambridge University Press, 1970.

Lagae, Johan. "In Search of a 'comme chez soi.' The Ideal Colonial House in Congo (1885-1960)." In Itinéraires croisés de la modernité Congo belge (1920-1950), edited by Jean-Luc Vellut, 239-281. Paris: L'Harmattan, 2001.

Lagae, Johan. "Le territoire urbain de Kinshasa: patchwork et palimpseste." In Kinshasa. Architecture et paysage urbains, edited by Marc Gemoets, Johan Lagae and Bernard Toulier, 9-21. Paris: Somogy Editions, 2010.

Lambertz, Peter. Seekers and Things: Spiritual Movements and Aesthetic Difference in Kinshasa. New York: Berghahn, 2018.

Lamy, Emile. “Antoine Sohier." Biographie Belge d'Outre-Mer, vol. 8, edited by Académie Royale des Sciences d'Outre-Mer, col. 392-406. Brussels: Librairie Falk fils, 1998.

Lanza, Hermelinde. "Stanleyville, ville cosmopolite. La localisation des différents groupes dans l'espace urbain." In Les mémoires du Congo. Le temps colonial, edited by Jean-Luc Vellut, 99-103. Gent: Éditions Snoeck, 2005.

Laqua, Daniel. The Age of Internationalism and Belgium, 1880-1930. Peace, Progress and Prestige. Manchester: Manchester University Press, 2013.

Lässig, Simone. Jüdische Wege ins Bürgertum. Kulturelles Kapital und sozialer Aufstieg im 19. Jahrhundert. Göttingen: Vandenhoeck \& Ruprecht, 2004.

Lauro, Amandine. Coloniaux, ménagères et prostituées au Congo belge (1885-1930). Brussels: Labor, 2005.

Lauro, Amandine."'J'ai honneur de porter plainte contre ma femme.' Litiges conjugaux et administration colonial au Congo belge (1930-1960)." CLIO. Histoire, femmes et societies 33 (2011): $65-84$.

Lauro, Amandine, and Valerie Piette. "Le Congo Belge. Coloniser sans élites?" In Au sommet de l'Empire. Les élites européennes dans les colonies (XVIe-XXe siècle), edited by Claire Laux, François-Joseph Ruggiu, and Pierre Singaravélou, 115-138. Brussels: Peter Lang, 2009.

Lauro, Amandine. "Suspect Cities and the (Re)Making of Colonial Order: Urbanisation, Security Anxieties and Police Reforms in Postwar Congo (1945-1960)." In Policing New Risks in Modern European History, edited by Jonas Campion and Xaxier Rousseaux, 57-85. London: Palgrave Macmillan, 2016.

Lauro, Amandine. "Women in the Democratic Republic of Congo." In Oxford Research Encyclopedia of African History, edited by Thomas Spear (May 2020), accessed March 10, 2021. doi: 10.1093/acrefore/9780190277734.013.544.

Lawrance, Benjamin N. Introduction to Intermediaries, Interpreters, and Clerks. African Employees in the Making of Colonial Africa, edited by Benjamin N. Lawrence, Emily Lynn Osborn, and Richard L. Roberts, 3-34. Wisconsin: University of Wisconsin Press, 2006.

Le Cour Grandmaison, Olivier. De l'indigénat. Anatomie d'un "monstre" juridique: le droit colonial en Algérie et dans l'Émpire français. Paris: Zone, 2015.

Lemarchand, René. Political Awakening in the Belgian Congo. Berkeley: University of California Press, 1964. 
Lemarchand, René. "The Limits of Self-Determination: The Case of the Katanga Secession." American Political Science Review 56, no. 3 (1962): 404- 416.

Lentz, Carola. "Constructing Ethnicity: Elite Biographies and Funerals in Ghana." In Ethnicity, Belonging and Biographies, edited by Gabriele Rosenthal and Artur Bogner, 181-202. Münster: Lit, 2009.

Lentz, Carola. "Doing Being Middle-Class in the Global South: Comparative Perspectives and Conceptual Challenges." Africa 90, no. 3 (2020): 439-469.

Lentz, Carola. "Elites or Middle Classes? Lessons from Transnational Research for the Study of Social Stratification in Africa." Working Papers of the Department of Anthropology and African Studies no. 161 (2015).

Lentz, Carola. "II Take an Oath to the State, not the Government.' Career Trajectories and Professional Ethics of Ghanaian Public Servants." In States at Work: Dynamics of African Bureaucracies, edited by Thomas Bierschenk and Jean-Pierre Olivier de Sardan, 175-204. Leiden: Brill, 2014.

Lentz, Carola. “'Tribalismus’ und Ethnizität in Afrika. Ein Forschungsüberblick.” Leviathan 23 (1995): $115-145$.

Levine, Philippa. "States of Undress: Nakedness and the Colonial Imagination." Victorian Studies 50, no. 2 (2008): $189-219$.

Levine, Philippa. "Naked Truths: Bodies, Knowledge, and the Erotics of Colonial Power." Journal of British Studies 52 (2013): 5-25.

Lewis, Su Lin. Cities in Motion. Urban Life and Cosmopolitanism in Southeast Asia, 1920 - 1940. Cambridge: Cambridge University Press, 2016.

Lind, Andrew W., ed. Race Relations in World Perspective. Honolulu: University of Hawaii Press, 1955.

Lindner, Rolf. "Bandenwesen und Klubwesen im wilhelminischen Reich und in der Weimarer Republik. Ein Beitrag zur historischen Kulturanalyse.” Geschichte und Gesellschaft 3 (1984): 325-375.

Lindner, Rolf. Die Stunde der Cultural Studies. Vienna: WUV, 2000.

Lindner, Rolf. Walks on the Wild Side. Eine Geschichte der Stadtforschung. Frankfurt am Main: Campus, 2004.

Lindner, Ulrike. Koloniale Begegnungen. Deutschland und Großbritannien als Imperialmächte in Afrika 1880-1914. Frankfurt am Main: Campus, 2011.

Little, Kenneth. "The African Elite in British West Africa." In Race relations in World Perspective, edited by Andrew William Lind, 263-288. Honolulu: University of Hawaii Press, 1955.

Little, Kenneth. "Voluntary Associations and Social Mobility among West African Women." Canadian Journal of African Studies 6 (1972): 275-288.

Little, Kenneth. West African Urbanization. A Study of Voluntary Associations and Social Change. Cambridge: Cambridge University Press, 1965.

Lloyd, Peter Cutt. Introduction to The New Elites of Tropical Africa, edited Peter Cutt Lloyd, 1-65, London: Routledge, 1966.

Loffman, Ruben A. Church, State and Colonialism in Southeastern Congo, 1890-1962.

Basingstoke: Palgrave, 2019.

Lomami-Tshibamba, Paul. Ngemena. Yaoundé: Cle, 1981.

López, Ricardo A., and Barbara Weinstein, eds. The Making of the Middle Class. Toward a transnational history. Durham: Duke University Press, 2012. 
Lotar, Léon. "Le Statut des Immatriculés." Congo 4 (1923): 451- 467.

Louis, William Roger. Ends of British Imperialism: The Scramble for Empire, Suez, and Decolonization. New York: I. B. Tauris, 2006.

Lumumba, Patrice. Le Congo, terre d'avenir, est-il ménacé? Brussels: Office de Publicité, 1961. Lynn, Martin. "Technology, Trade and 'A Race of Native Capitalists': The Krio Diaspora of West African and the Steamship, 1852-95." Journal of African History 33 (1992): 421-440.

Maier, Charles S. Recasting Bourgeois Europe: Stabilization in France, Germany, and Italy in the Decade after World War I. Princeton: Princeton University Press, 1975.

Malengreau, Guy. “La formation politique des Congolais.” Problèmes d'Afrique centrale 14, no. 4 (1951): $269-278$.

Malinowski, Stephan. "Modernisierungskriege. Militärische Gewalt und koloniale Modernisierung im Algerienkrieg (1945-1962)." AfS 48 (2008): 213-248.

Mann, Gregory. "What was the Indigénat? The Empire of Law in French West Africa." Journal of African History 50, no. 3 (2009): 331-353.

Mann, Kristin. Marrying Well. Marriage, Status and Social Change among the Educated Elite in Colonial Lagos. Cambridge: University of Cambridge Press, 1985.

Mann, Kristin, and Richard L. Roberts. Law in Colonial Africa. London: James Currey, 1991. Mannheim, Karl. Mensch und Gesellschaft im Zeitalter des Umbaus. Leiden: A.W.Sijthoff's Uitgeversmaatschappij N.V., 1935.

Markowitz, Marvin D. Cross and Sword. The Political Role of Christian Missions in the Belgian Congo, 1908-1960. Stanford: Hoover Institution Press, 1973.

Martin, Phyllis M. "Contesting, Clothes in Colonial Brazzaville." Journal of African History 35, no. 3 (1994): 401-426.

Martin, Phyllis M. Leisure and Society in Colonial Brazzaville. Cambridge: Cambridge University Press, 2002.

Martschukat, Jürgen, and Olaf Stieglitz. Geschichte der Männlichkeiten. Frankfurt am Main: Campus, 2008.

Marx, Christoph. Geschichte Afrikas. Von 1800 bis zur Gegenwart. Paderborn: UTB, 2004.

Marx, Christoph. "Siedlerkolonien in Afrika. Versuch einer Typologie." In Rassenmischehen Mischlinge - Rassentrennung. Zur Politik der Rasse im deutschen Kolonialreich, edited by Frank Becker, 82-96. Stuttgart: Franz Steiner, 2004.

Marx, Christoph. "Verwoerdian Apartheid and African Political Elites in South Africa, 1950-1968." In Elites and Decolonization in the Twentieth Century, edited by Jost Dülffer and Marc Frey, 138-156. Basingstoke: Palgrave Macmillan, 2011.

Maß, Sandra. Weiße Helden, schwarze Krieger. Zur Geschichte kolonialer Männlichkeit in Deutschland 1918-1964. Cologne: Böhlau, 2006.

Matera, Marc. Black London: The Imperial Metropolis and Decolonization in the 20th Century. Oakland: University of California Press, 2015.

Mazrui, Ali A. Political Values and the Educated Class in Africa. Berkeley: University of California Press, 1978.

Mazrui, Ali A. "Seek ye First the Political Kingdom." In Africa since 1935, vol. 8, edited by Ali A. Mazrui, 105-126. Paris: UNESCO, 1993.

Mbembe, Achille. Sortir de la grande nuit: Essai sur l'Afrique décolonisée. Paris: La Découverte, 2013. 
M'Bokolo, Elikia. “Forces sociales et idéologies dans la décolonisation de L’A.E.F." Journal of African History 22, no. 3 (1981): 393- 407.

Mbungu Nkandamana, Joseph. L'indépendance du Congo belge et l'avènement de Lumumba. Témoignage d'un acteur politique. Paris: L'Harmattan, 2008.

McClellan, Woodford. "Africans and Black Americans in the Comintern Schools, 1925-1934." International Journal of African Historical Studies 26 (1993): 371-390.

Melber, Henning, ed. The Rise of Africa's Middle Class: Myths, Realities and Critical Engagements. London: Zed Books, 2016.

Mercer, Claire, and Charlotte Lemanski. Introduction to Africa 90, no. 3 (2020): 429-438.

Mergel, Thomas. Zwischen Klasse und Konfession. Katholisches Bürgertum im Rheinland 1794-1914. Göttingen: Vandenhoeck \& Ruprecht, 1994.

Merle, Isabelle. Expériences Coloniales. La Nouvelle-Calédonie. 1853-1920. Paris: Belin, 1995. Merle, Isabelle. "L’État français, le droit et la violence coloniale: Le régime de l'indigénat." In Figurationen des Staates in Deutschland und Frankreich 1870-1945, edited by Alain Chatriot and Dieter Gosewinkel, 97-116. Munich: Oldenbourg, 2006.

Metzler, Gabriele. "Einleitung." In Das Andere denken. Repräsentationen von Migration in Westeuropa und den USA im 20. Jahrhundert, edited by Gabriele Metzler, 9-15. Frankfurt am Main: Campus, 2013.

Meyerrose, Anja. Herren im Anzug. Eine transatlantische Geschichte von Klassengesellschaften im langen 19. Jahrhundert. Vienna: Böhlau, 2016.

Mianda, Gertrude. "Colonialism, Education and Gender Relations in the Belgian Congo. The Évolué Case.” In Women in African Colonial Histories, edited by Jean Allman, Susan Geiger, and Nakanyike Musis, 144-163. Bloomington: Indiana University Press, 2002.

Mianda, Gertrude. "L'état, le genre et l'iconographie. L'image de la femme au Congo belge." In Images, mémoires et savoirs. Une histoire en partage avec Bogumil Koss Jewsiewicki, edited by Isodore Ndaywel è Nziem and Elisabeth Mudimbe-Boyi, 515-537. Paris: Karthala, 2009.

Miescher, Stephan F. Making Men in Ghana. Bloomington: Indiana University Press, 2005.

Miller, Monica L. "W. E. B. Du Bois and the Dandy as Diasporic Race Man." Callaloo 26, no. 3 (2003): $738-765$.

Mohan, Jitendra. "Ghana, Congo, and the United Nations." Journal of Modern African Studies 7, no. 3 (1969): $365-406$.

Mollin, Gerhard Th. USA und der Kolonialismus. Amerika als Partner und Nachfolger der belgischen Macht in Afrika, 1939-1965. Berlin: De Gruyter, 1996.

Monaville, Pedro. "A History of Glory and Dignity: Patrice Lumumba in Historical Imagination and Postcolonial Genealogies." In Lumumba in the Arts, edited by Matthias de Groof, 62-77. Leuven: Leuven University Press, 2020.

Morton, David. "From Racial Discrimination to Class Segregation in Postcolonial Urban Mozambique." In Geographies of Privilege, edited by France Winddance Twine and Bradley Gardner, 231-261. New York: Routledge, 2013.

Moyn, Samuel. The Last Utopia. Human Rights in History. Cambridge: Cambridge University Press, 2010.

Mudimbe, Valentin-Yves, ed. The Surreptitious Speech. Présence Africaine and the Politics of Otherness. Chicago: University of Chicago Press, 1992. 
Mutamba-Makombo, Jean-Marie. Du Congo belge au Congo indépendant. Émergence des ,évolués' et genèse du nationalisme. Kinshasa: Publications de l'Institut de formation et études politiques, 1998.

Mutamba-Makombo, Jean-Marie. "Im Salon eines kongolesischen Évolué in den vierziger und fünfziger Jahren.” In An-Sichten. Malerei aus dem Kongo, 1990-2000, edited by Bogumil Jewsiewicki and Barbara Plankensteiner, 153-157. Wien: Springer, 2001.

Mutamba-Makombo, Jean-Marie. "Les auteurs du manifeste de 'Conscience Africaine': blancs ou noirs?” In Images, mémoires et savoirs. Une histoire en partage avec Bogumil Koss Jewsiewicki, edited Isodore Ndaywel è Nziem and Elisabeth Mudimbe-Boyi, 611-624. Paris: Karthala, 2009.

Mutamba-Makombo, Jean-Marie. “Les évolués. Situation au Congo Belge.” In Le manifeste “Conscience africaine” (1956). Élites congolaises et société coloniale. Regards croisés, edited by Nathalie Tousignant, 83-115. Brussels: Presses de l'Université Saint-Louis, 2009.

Mutamba-Makombo, Jean-Marie. Patrice Lumumba, correspondant de presse, 1948-1956. Paris: L'Harmattan, 2005.

Mutombo, Dieudonné. Victoire de l'amour. Leverville: Bibliothèque de l'Étoile, 1959.

Mwissa-Camus, C. A. L'héritage Tata Raphael. 1911-2011. Un siècle d'histoire à Kinshasa avec les pères de Scheut. Kinshasa 2011.

Nadel, Siegfried Frederick. "The Concept of Social Elites." International Social Science Bulletin 8 (1956): $413-424$.

Ndaywel è Nziem, Isidore. Histoire générale du Congo. De l'héritage ancien à la République Démocratique. Paris: Duculot, 1998.

Newell, Stephanie. "Entering the Territory of Elites. Literary Activity in Colonial Ghana." In Readings in African Popular Culture, edited by Karin Barber, 211-235. Bloomington: Indiana University Press, 2005.

Newell, Stephanie. "How to Play the Game of Life." Literary Culture in Colonial Ghana. Manchester: Manchester University Press, 2002.

Newell, Stephanie. The Power to Name. A History of Anonymity and Colonial West Africa. Athens: Ohio University Press, 2013.

Nkrumah, Kwame. Challenge of the Congo. New York: Panaf, 1967.

Nnang Ndong, Léon Modeste. L'effort de guerre de l'Afrique. Le Gabon dans la deuxième guerre mondiale. Paris: L'Harmattan, 2011.

Norton, William B. “Review." African Historical Studies 3, no. 1 (1969): 158-164.

Nzongola-Ntalaja, Georges. The Congo. From Leopold to Kabila. A People's History. New York: Zed Books, 2002.

Odhiambo, Tom. "Inventing Africa in the Twentieth Century: Cultural Imagination, Politics and Transnationalism in Drum Magazine." African Studies 65, no. 2 (2006): 157-174.

Osterhammel, Jürgen. Die Verwandlung der Welt. Eine Geschichte des 19. Jahrhunderts. München: C.H. Beck, 2009.

Osterhammel, Jürgen. "Hierarchies and Connections: Aspects of a Global Social History." In An Emerging Modern World: 1750-1870, edited by Sebastian Conrad and Jürgen Osterhammel, 663-890. Cambridge: Harvard University Press, 2018.

Osterhammel, Jürgen. Kolonialismus. Geschichte - Formen - Folgen. Munich: C. H. Beck, 1997. 
Osterhammel, Jürgen. The Transformation of the World. A Global History of the Nineteenth Century. Princeton: Princeton University Press, 2014.

Osterhammel, Jürgen, and Jan C. Jansen. Dekolonisation. Das Ende der Imperien. München: C. H. Beck, 2013.

Parsons, Timothy H. Race, Resistance, and the Boy Scout Movement in British Colonial Africa. Athens: Ohio University Press, 2004.

Pasquier, Roger. La jeunesse ouvrière chrétienne en Afrique noire (1930-1950). Paris: Karthala, 2013.

Pernau, Margrit. Bürger mit Turban. Muslime in Delhi im 19. Jahrhundert. Göttingen: Vandenhoeck \& Ruprecht, 2008.

Pernau, Margrit. "Transkulturelle Geschichte und das Problem der universalen Begriffe. Muslime Bürger im Delhi des 19. Jahrhunderts." In Area Studies und die Welt. Weltregionen und neue Globalgeschichte, edited by Birgit Schäbler, 117-149. Vienna: Mandelbaum Verlag, 2007).

Pesek, Michael. Das Ende eines Kolonialreiches. Ostafrika im Ersten Weltkrieg. Frankfurt am Main: Campus, 2010.

Pesek, Michael. "Der koloniale Körper in der Krise. Koloniale Repräsentationen, Ordnung und Gewalt während des Ersten Weltkriegs in Ostafrika, 1914-1918.” In Dem Anderen Begegnen. Eigene und fremde Repräsentationen in sozialen Gemeinschaften, edited by Jörg Baberowski, David Feest, and Maike Lehmann, 59-81. Frankfurt am Main: Campus, 2009.

Pesek, Michael. "Die Kunst des Reisens. Die Begegnung von europäischen Forschungsreisenden und Ostafrikanern in den Kontaktzonen des 19. Jahrhunderts." In Erinnerungsräume und Wissenstransfer. Beiträge zur afrikanischen Geschichte, edited by Winfried Speitkamp, Jürgen Reulecke and Birgit Neumann, 65-99. Göttingen: Vandenhoeck \& Ruprecht, 2008.

Pesek, Michael. Koloniale Herrschaft in Deutsch-Ostafrika. Expedition, Militär und Verwaltung seit 1880. Frankfurt am Main: Campus, 2005.

Pesek, Michael. Pesek, "Performing the Metropolitan Habitus. Images of European Modernity in Cross-Cultural Encounters in Nineteenth Century Eastern Africa." In Figurations of Modernity. Global and Local Representations in Comparative Perspective, edited by Vincent Houben and Mona Schrempf, 41-65. Frankfurt am Main: Campus, 2008.

Peterson, Derek R., Emma Hunter, and Stephanie Newell, eds. African Print Cultures. Newspapers and their Publics in the Twentieth Century. Ann Arbor: University of Michigan Press, 2016.

Pétillon, Léon. Récit-Congo 1929-1958. Brussels: La Renaissance du Livre, 1985.

Picton, John, and John Mack. African Textiles: Looms, Weaving and Design. London: Textile Museum, 1979.

Piette, Valérie. "Conscience Africaine et inconscience belge." In Le Manifeste "Conscience africaine” (1956). Élites congolaises et société coloniale. Regards croisés, edited by Nathalie Tousignant, 39-57. Brussels: Presses de l'Université Saint-Louis, 2009.

Plageman, Nate. “'Accra is changing, isn't it?' Urban Infrastructure, Independance, and Nation in The Gold Coast's 'Daily Graphic,' 1954-1957." International Journal of African Historical Studies 43, no. 1 (2010): 137-159.

Plankensteiner, Barbara. "Wo die Bilder wohnen. Eine Ethnographie des Wohnzimmers und Wandschmucks im urbanen Kongo.” In An-Sichten. Malerei aus dem Kongo, 1990-2000, 
edited by Barbara Plankensteiner and Bogumil Jewsiewicki, 139-153. Vienna: Springer, 2001.

Plummer, Ken. "On the Diversity of Life Documents." In Social Research Methods: A Reader, edited by Clive Seale, 282-289. London: Routledge, 2004.

Pochmara, Anna. The Making of the New Negro. Black Authorship, Masculinity, and Sexuality in the Harlem Renaissance. Amsterdam: Amsterdam University Press, 2011.

Poncelet, Marc. "Colonisation, développement et sciences sociales. Éléments pour une sociologie de la constitution du champ des arts et sciences du développement dans les sciences sociales francophones belges." Bulletin de l'APAD 6 (1993): 360-364.

Pons, Valdo. Stanleyville. An African Urban Community under Belgian Administration. London: Oxford University Press, 1969.

Porter, Bernard. Absent-Minded Imperialists: Empire, Society, and Culture in Britain. Oxford: Oxford University Press, 2004.

Prais, Jinny K. "Representing an African City and Urban Elite. The Nightclubs, Dance Halls, and Red Light District of Interwar Accra." In The Arts of Citizenship in African Cities, edited by Rosalind Fredericks and Mamadou Diouf, 118-207. New York: Palgrave Macmillan, 2014.

Puissant, Jean. "Le bon ouvrier, mythe ou réalité du XIXe siècle. De l'utilité d'une biographie. J. F. J. Dauby (1824-1899)." Revue belge de philologie et d'histoire 56 (1979): 878-929.

Quaghebeur, Marc, and Bibiane Tshibola Kalengayi, eds. Aspects de la culture à l'époque coloniale en Afrique centrale. Presse-Archive. Paris: L'Harmattan, 2008.

Quaghebeur, Marc. "Des textes sous le boisseau." In Papier blanc, encre noire. Cent ans de culture francophone en Afrique centrale (Zaïre, Rwanda, Burundi), edited by March Quaghebeur and Emil Balberghe, VII-LIX. Brussels: Labor, 1992.

Reinhard, Wolfgang. "Dialektik des Kolonialismus. Kolonialismus und die Anderen." In Europa und die Dritte Welt. Kolonialismus - Gegenwartsprobleme -

Zukunftsperspektiven, edited by Klaus J. Bade and Dieter Brötel, 5-25. Hannover: Metzler, 1992.

Reimann, Christina. Schule für Verfassungsbürger? Die Bildungsligen und der Verfassungswandel des späten 19. Jahrhunderts in Belgien, England und Frankreich. Münster: Waxmann, 2016.

Reynebeau, Marc. Histoire belge: 1830-2005. Brussels: Racine, 2005.

Reyntjens, Filip. “Antoine Rubbens." In Biographie belge d'outre-mer, vol. 9, edited by Académie Royale Science d'Outre-Mer, coll. 332-336. Brussels: Librairie Falk fils, 2015. Reyntjens, Filip. "Van Bilsen." In Biographie belge d'outre-mer, vol. 9, edited by Académie Royale Science d'Outre-Mer, 379-383. Brussels: Librairie Falk fils, 2015.

Riesz, János. Léopold Sédar Senghor und der afrikanische Aufbruch ins 20. Jahrhundert. Wuppertal: Peter Hammer, 2006.

Riva, Silvia. Nouvelle histoire de la littérature du Congo-Kinshasa. Paris: L'Harmattan, 2006.

Robinson, Ronald. "Non European Foundations of European Imperialism: Sketch for a Theory of Collaboration." In Studies in the Theory of Imperialisms, edited by Roger Owen and Bob Sutcliffe, 117-141. London: Longman, 1972.

Ross, Robert. "Missions, Respectability and Civil Rights: The Cape Colony, 1828-1854." Journal of Southern African Studies 25, no. 3 (1999): 333-345.

Ross, Robert. Status and Respectability in the Cape Colony. Cambridge: Cambridge University Press, 1999. 
Rubbens, Antoine, ed. Dettes de Guerre, Elisabethville: Editions de l'Essor du Congo, 1945. Rubbens, Antoine. "Jean Sepulchre.” In Biographie Belge d'Outre-Mer, vol. 7-B, edited by Académie Royale des Sciences d'Outre-Mer, col. 340-342. Brussels: Librairie Falk fils, 1977.

Rubbens, Antoine. “Perspective démocratique au Congo Belge.” La Revue Nouvelle 6 (1947): 453.

Rubbens, Antoine. "Pierre Piron." In Biographie Belge d'Outre-Mer, vol. 7-B, edited by Académie Royale des Sciences d'Outre-Mer. Brussels: Librairie Falk fils, 1977.

Rubbers, Benjamin. Faire fortune en Afrique. Anthropologie des derniers colons du Katanga. Paris: Karthala, 2009.

Ryckmans, Pierre. Dominer pour servir. Brussels: Éditions universelles, 1948.

Saada, Emmanuelle. "Citoyens et sujets de l'Empire français. Les usages du droit en situation coloniale." Genèses 53, no. 4 (2003): 4-24.

Saada, Emmanuelle. Empire's Children. Race, Filiation, and Citizenship in the French Colonies. Chicago: University of Chicago Press, 2012.

Saada, Emmanuelle. 'Entre 'assimilation' et 'décivilisation.' L'imitation et le projet colonial républicain.” Terrain. Revue d'éthnologie de l'Europe 44 (2005): 19-38.

Saada, Emmanuelle. Les enfants de la colonie. Les métis de l'Empire français entre sujétion et citoyenneté. Paris: La Découverte, 2007.

Saada, Emmanuelle. "The Empire of Law. Dignity, Prestige, and Domination in the Colonial Situation." French Politics, Culture and Society 20 (2002): 98-120.

Saada, Emmanuelle. "Une qualité par degré. Civilité et citoyenneté en situation coloniale." In L'esclavage, la colonisation, et après. France, États-Unis, Grande-Bretagne, edited by Patrick Weil and Stéphane Dufoix, 193-228. Paris: PUF, 2005.

Sabakinu Kivilu, Jacob. "Paul-Gabriel Dieudonné Bolya: de l'assistant médical à l'homme politique." In Les mémoires du Congo. Le temps colonial, edited by Jean-Luc Vellut, 235-239. Gent: Éditions Snoeck, 2005.

Sarasin, Philipp. "Subjekte, Diskurse, Körper. Überlegungen zu einer diskursanalytischen Kulturgeschichte." Geschichte und Gesellschaft, special issue 16: Kulturgeschichte heute, edited by Wolfgang Hardtwig and Hans-Ulrich Wehler, 131-164. Göttingen: Vandenhoeck \& Ruprecht.

Sartre, Jean-Paul. Preface to La pensée politique de Patrice Lumumba," edited by Jean Van Lierde, I-XLV. Paris: Présence Africaine, 1964.

Schaper, Ulrike. "Entanglements and Interactions within the Plural Legal Order: The Case of the German Colony Cameroon 1884-1916." In One Law for All. Western Models and Local Practices in (Post-)Imperial Contexts, edited Stefan B. Kirmse, 243-264. Frankfurt am Main: Campus, 2012.

Schaper, Ulrike. Koloniale Verhandlungen. Gerichtsbarkeit, Verwaltung und Herrschaft in Kamerun 1884-1916. Frankfurt am Main: Campus, 2012.

Schaper, Ulrike. "Law and Colonial Order. Legal Policy in German Cameroon between Civilising and Public Peace." Comparativ. Zeitschrift für Globalgeschichte und vergleichende Gesellschaftsforschung 19 (2009): 17-33.

Schär, Bernhard C. Tropenliebe: Schweizer Naturforscher und niederländischer Imperialismus in Südostasien um 1900. Frankfurt am Main: Campus, 2015.

Schulz, Andreas. Lebenswelt und Kultur des Bürgertums im 19. und 20. Jahrhundert. München: De Gruyter, 2005. 
Scotton, James F. "The first African press in East Africa: Protest and Nationalism in Uganda in the 1920s.” The International Journal of African Historical Studies 6 (1973): 211-228.

Searing, James F. West African Slavery and Atlantic Commerce. The Senegal River Valley, 1700-1860. Cambridge: Cambridge University Press, 1993.

Seibert, Julia. In die globale Wirtschaft gezwungen. Arbeit und kolonialer Kapitalismus im Kongo (1885-1960). Frankfurt am Main: Campus, 2016.

Seibert, Julia. "Winds of Change: Worker's Unrest and the Transformation of Colonial Capitalism in Katanga, Belgian Congo." In Travail et culture dans un monde globalisé. De l'Afrique à l'Amerique latine, edited by Andreas, Babacar Fall and Ineke PfaffRheinberger, 253-272. Paris: Karthala, 2013.

Sekyi, Kobina. The Blinkards and the Anglo-Fanti. A Comedy. London: Rex Collings, 1974.

Semley, Lorelle. To Be Free and French. Citizenship in France's Atlantic Empire. Cambridge: Cambridge University Press, 2017.

Servaes, Jan. "Concentration and Competition in the Belgian Press." Communications 16, no. 3 (1998): 363-377.

Sharkey, Heather J. "African Colonial States." In The Oxford Handbook of Modern African History, edited by John Parker and Richard Reid, 151-171. Oxford: Oxford University Press, 2013.

Shepard, Todd. The Invention of Decolonization. The Algerian War and the Remaking of France. New York: Cornell University Press, 2006.

Sibeud, Emmanuelle, and Marie-Albaine De Suremain. "'Histoire coloniale' et/ou 'colonial studies,' d'une histoire à l'autre." In Écrire l'histoire de l'Afrique autrement?, edited by Pascale Bartelemy, Séverine Awenengo and Charles Tshimanga, 73-87. Paris: L'Harmattan, 2004.

Sinha, Mrinalini. "Britishness, Clubbability and the Colonial Public Sphere. The Genealogy of an Imperial Institution in Colonial India." Journal of British Studies 40, no. 4 (2001): 489-521.

Sinha, Mrinalini. Colonial Masculinity: The manly Englishman and The Effeminate Bengali in the Late Nineteenth Century. Manchester: Manchester University Press, 1995.

Sliwinski, Sharon. "The Childhood of Human Rights: The Kodak on the Congo." Journal of Visual Culture 5, no. 3 (2006): 333-363.

Sohier, Antoine. "La politique d'intégration.” Zaïre 11, no. 5 (1951): 899-928.

Sohier, Antoine. "Le problème des indigènes évolués et la commission du statut des congolaises civilisés.” Zaïre 8, no. 3 (1949): 843-880.

Sohier, Antoine. "Le statut personnel des autochtones au Congo Belge." Civilisations 3, no. 2 (1953): $179-187$.

Southall, Aidan William. "The Concept of Elites and their Formation in Uganda." In The New Elites of Tropical Africa, edited by Peter Cutt Lloyd, 342-366. London: Routledge, 1966.

Stanard, Matthew G. "Belgium, the Congo, and Imperial Immobility: A Singular Empire and the Historiography of the Single Analytical Field." French Colonial History 15 (2014): 87-109.

Stanard, Mathew G. Selling the Congo. A History of European Pro-Empire Propaganda and the Making of Belgian Imperialism. Lincoln: University of Nebraska, 2012.

Stein, Gerd, ed. Dandy - Snob - Flaneur. Dekadenz und Exzentrik. Kulturfiguren und Sozialcharaktere des 19. und 20. Jahrhunderts. Frankfurt am Main: Fischer, 1985. Stengers, Jean. Congo, mythes et réalités. Brussels: Racine, 2005. 
Stenmans, Alain, and Jean Charlier. “Pierre Wigny.” In Biographie Belge d'Outre-Mer, vol. 9, edited by Académie Royale des Sciences d'Outre-Mer, col. 433-440. Brussels: Librairie Falk fils, 2015.

Stenmans, Alain, and Filip Reyntjens. La pensée politique du gouverneur général Pétillon. Brussels: Académie royale des sciences d'outre-mer, 1993.

Stöckle, Frieder. "Zum praktischen Umgang mit Oral History." In Oral History. Mündlich erfragte Geschichte. Acht Beiträge, edited by Herwert Vorländer, 131-158. Göttingen: Vandenhoeck \& Ruprecht, 1990.

Stoler, Ann Laura. Along the Archival Grain: Epistemic Anxieties and Colonial Common Sense. Princeton: Princeton University Press, 2009.

Stoler, Ann Laura. "Making Empire Respectable: The Politics of Race and Sexual Morality in 20th Century Colonial Cultures." American Ethnologist 16 (1989): 634-660.

Stoler, Ann Laura. Race and the Education of Desire. Foucault's History of Sexuality and the Colonial Order of Things. Durham: Duke University Press, 1995.

Stoler, Ann Laura. "Rethinking Colonial Categories. European Communities and the Boundaries of Rule." Comparative Studies in Society and History 31 (1989): 134-161.

Storme, M., and P. Dephoperé. "Raphael de la Kethulle de Ryhove." In Biographie Belge d'Outre-Mer, vol. 6, ed. Académie Royale des Sciences d'Outre-Mer, col. 573-576. Brussels: Librairie Falk fils, 1968.

Strouvens, Léon, and Pierre Piron. Codes et lois du Congo belge. Léopoldville: Édition des Codes et Lois du Congo Belge, 1948.

Switzer, Les. "Introduction. South Africa's Alternative Press in Perspective." In South Africa's Alternative Press. Voices of Protest and Resistance, edited by Les Switzer, 1-54. Cambridge: Cambridge University Press, 1997.

Tamme, Reet. "Von den dark strangers zum Subproletariat: Wissenschaftliche Deutungen der multiethnischen Gesellschaft in Großbritannien von den 1950er bis Anfang der 1970er Jahre." In Das Andere denken. Repräsentationen von Migration in Westeuropa und den USA im 20. Jahrhundert, edited by Gabriele Metzler, 119-153. Frankfurt am Main: Campus, 2013.

Thackeray, William Makepeace. Book of Snobs. London: Punch, 1868.

Thomas, Dominic. "Fashion Matters. 'La Sape' and Vestimentary Codes in Transnational Contexts and Urban Diasporas.” Modern Language Notes 118 (2003): 947-973.

Thompson, Andrew S. The Empire Strikes Back? The Impact of Imperialism on Britain from the Mid-nineteenth Century. New York: Routledge, 2005.

Tidrick, Katryn. Empire and the English Character. London: Bloomsbury, 1992.

Tilman, Samuel. "L'implantation du scoutisme au congo belge." In Itinéraires croisés de la modernité Congo belge (1920-1950), edited by Jean-Luc Vellut, 103-140. Paris: L'Harmattan, 2001.

Tischler, Julia. Light and power for a multiracial nation: the Kariba Dam scheme in the Central African Federation. Basingstoke: Palgrave Macmillan, 2013.

Tödt, Daniel. “L’État colonial et les élites africaines, une histoire de soumission?" In Le Congo Colonial. Une histoire en questions, edited by Idesbald Goddeeris, Amandine Lauro, and Guy Vanthemsche, 265-278. Waterloo: Renaissance du Livre, 2020.

Tödt, Daniel, and Söhnke Vosgerau. "Ethnizität und Ethnische Repräsentationen im Fußball. Am Beispiel Türkiyemspor Berlin.” In Aus der Halbdistanz. Fußballbiografien und 
Fußballkulturen heute, edited by Stefan Krankenhagen and Birger Schmidt, 115-137. Münster: Lit, 2007.

Toll, Robert C. Blacking Up: The Minstrel Show in Nineteenth-Century America. New York: Oxford University Press, 1974.

Tousignant, Nathalie, ed. Le manifeste "Conscience africaine" (1956). Elites congolaises et société coloniale. Regards croisés. Brussels: Presses de l'Université Saint-Louis, 2009.

Tshimanga, Charles. Jeunesse, formation et société au Congo/Kinshasa 1890-1960. Paris: L'Harmattan, 2001.

Tshimanga, Charles. "L'ADAPES et la formation d'une élite au Congo (1925-1945)." In Itinéraires croisés de la modernité Congo belge (1920-1950), edited by Jean-Luc Vellut, 189-204. Paris: L'Harmattan, 2001.

Tshonda, Jean Omasombo, and Benoît Verhaegen. Patrice Lumumba: Acteur politique. De la prison aux portes du pouvoir, juillet 1956-février 1960. Paris: L'Harmattan, 2005.

Tshonda, Jean Omasombo, and Nathalie Delaleeuwe. "Je veux la civilisation, mais le Blanc ne veut pas de moi' ou le drame du Congo belge au travers de son élite.” In Le manifeste ,Conscience africaine“ (1956). Élites congolaises et sociétés coloniales. Regards croisées, edited by Nathalie Tousignant, 141-206. Brussels: Presses de l'Université Saint-Louis, 2009.

Tshonda, Jean Omasombo, and Benoît Verhaegen. Patrice Lumumba: Jeunesse et apprentissage politique, 1925-1956. Paris: L'Harmattan, 1998.

Tshonda, Jean Omasombo, and Benoît Verhaegen. "Patrice Lumumba et la guerre des bières." In Patrice Lumumba entre Dieu et Diable, edited by Pierre Halen and Jànos Riesz, Paris: L'Harmattan, 1997.

Turner, Terence S. "The Social Skin." In Not Work Alone. A Cross-Cultural View of Activities Superfluous to Survival, edited by Jeremy Cherfass and Roger Lewin, 112-140. London: Temple Smith, 1980.

Van Bilsen, Jef. Vers l'indépendance du Congo et du Ruanda-Urundi. Kinshasa: Presses universitaires du Zaïre, 1977.

Van Bol, Jean-Marie. La presse quotidienne au Congo Belge. Brussels: Pensée catholique, 1959.

Vandelinden, Jacques. Pierre Ryckmans. 1891-1959. Coloniser dans l'honneur. Brussels: De Boeck Université, 1994.

Van den Bersselaar, Dmitri. “'Doorway to Success?': Reconstructing African Careers in European Business from Company House Magazines and Oral History Interviews." African History 38 (2011): 257-294.

Van den Bersselaar, Dmitri. The King of Drinks. Schnapps Gin from Modernity to Tradition. Leiden: Brill, 2007.

Van den Bersselaar, Dmitri. "White-Collar Workers." In General Labor History of Africa. Workers, Employers and Governments, $20^{\text {th }}-21^{\text {st }}$ Centuries, edited by Stefano Bellucci and Andreas Eckert, 379-404. Suffolk: Boydell \& Brewer, 2019.

Vanderpelen-Diagre, Cécile. Écrire en Belgique sous le regard de Dieu. La littérature catholique belge dans l'entre deux guerres. Brussels: Complexe, 2004.

Vanhove, Julien. "Social Service in the Belgian Congo. Present Situation and Future Plans." Civilisations 1 (1951): 22-27.

Vanhove, Julien. "Capelle." In Biographie belge d'outre-mer, vol. 7-A, edited by Académie Royale Science d'Outre-Mer. Brussels: Librairie Falk fils, 1973. 
Van Osselaer, Tine. "Christening Masculinity? Catholic Action and Men in Interwar Belgium." Gender \& History 21, no.2 (2009): 380-401.

Van Osselaer, Tine. The Pious Sex. Catholic Constructions of Masculinity and Femininity in Belgium, 1800-1940. Leuven: Leuven University Press, 2014.

Van Osselaer, Tine. "Religion, Family and Domesticity in the Nineteenth and Twentieth Centuries. An Introduction." In Christian Homes. Religion, Family and Domesticity in the $19^{\text {th }}$ and $20^{\text {th }}$ Centuries, edited by Tine Van Osselaer and Patrick Pasture, 7-25. Leuven: Leuven University Press, 2014.

Van Peel, Bénédicte. "Débuts du football congolais." In Itinéraires croisés de la modernité Congo belge (1920-1950), edited by Jean-Luc Vellut, 141-188. Paris: L’Harmattan, 2001.

Van Reybrouck, David. Congo. Een geschiedenis. Amsterdam: De Bezige Bij, 2010.

Van Rompaey, Lies. "The Development of the Catholic Youth Organizations in the Belgian Congo (1908-1960)." In The Colonial Experience in Education. Historical Issues and Perspectives, edited by Antonio Nóvoa and Marc Depaepe, 193-213. Gent: CSHP, 1995.

Van Ruyskensvelde, Sarah, Karen Hulstaert, and Marc Depaepe. "The Cult of Order: In Search of Underlying Patterns of the Colonial and Neo-Colonial 'Grammar of Educationalisation' in the Belgian Congo. Exported School Rituals and Routines?" Paedagogica Historica 53 (2017): 36-48.

Vansina, Jan. Being Colonized. The Kuba Experience in Rural Congo, 1880-1960. Madison: University of Wisconsin Press, 2010.

Vanthemsche, Guy. Belgium and the Congo 1885-1980. Cambridge: Cambridge University Press, 2012.

Vanthemsche, Guy. "De Belgische socialisten en Congo." Brood en Rozen 4 (1999): 31-65.

Vanthemsche, Guy. "De Belgische spaarbanken in België tijdens de Interbellum." In De Belgische Spaarbanken. Geschiedenis, recht, economische functie en instellingen, edited by Belgische Spaarbankevereiniging, 166-209. Tielt: Lanoo, 1986.

Vanthemsche, Guy. Genèse et portée du "Plan Décennal" du Congo belge (1949-1959). Brussels: Académie Royale Science d'Outre-Mer, 1994.

Vanthemsche, Guy. Introduction to Les classes sociales en Belgique. Deux siècles d'histoire, edited by Guy Vanthemsche, 5-20. Brussels: CRISP, 2017.

Vanthemsche, Guy. La Belgique et le Congo. Brussels: Parole Silence, 2007.

Vanthemsche, Guy, ed. Les classes sociales en Belgique. Deux siècles d'histoire. Brussels: CRISP, 2017.

Vanthemsche, Guy. “The Belgian Colonial Empire (1885/1908-1906)." In Imperien und Reiche in der Weltgeschichte. Epochenübergreifende und globalhistorische Vergleiche, edited by Michael Gehler and Robert Rollinger, 971-996. Wiesbaden: Harrassowitz, 2014.

Van Wing, Joseph. "La formation d'une élite noire au Congo Belge." Bulletin C.E.P.S.I. 5 (1948): 8-22.

Vellut, Jean-Luc. "Albert Decoster." In Biographie Belge d'Outre-Mer, vol. 8, edited by Académie Royale Science d'Outre-Mer, col. 80-88. Brussels: Librairie Falk fils, 1998.

Vellut, Jean-Luc. Congo. Ambitions et desenchantements 1880-1960. Paris: Karthala, 2017.

Vellut, Jean-Luc. "Hégemonies en construction. Articulations entre État et entreprises dans le bloc colonial belge (1908-1960)." Canadian Journal of African Studies 16 (1982): 313-330. 
Vellut, Jean-Luc. Simon Kimbangu 1921: de la prédication a la déportation. Les sources. Brussels: Académie Royale des Sciences d'Outre Mer, 2010.

Verhaegen, Benoît. "Communisme et anticommunisme au Congo (1920-1960)." Brood en Rozen 4 (1999): 113-127.

Verhaegen, Benoît. L'ABAKO (Association des Bakongo) 1950-1960, documents. Brussels: Centre de recherche et d'information socio-politiques, 1962.

Verhaegen, Benoît. L'ABAKO et l'indépendance du Congo belge. Dix ans de nationalisme kongo (1950-1960). Paris: L'Harmattan, 2003.

Verhaegen, Benoît. L'Association des Évolués de Stanleyville et les débuts politiques de Patrice Lumumba (1944-1958). Brussels: CEDAF/ASDOC, 1982.

Verhaegen, Benoît. "Les associations congolaises à Léopoldville et dans le Bas-Congo avant 1960." Cahiers économiques et sociaux 8 (1970): $389-416$.

Verhaegen, Benoît. Les premiers manifestes politiques à Léopoldville. Brussels: CEDAF/ ASDOC, 1971.

Viaene, Vincent. "Vers une histoire de l'internationalisme catholique au XIXe siècle." Schweizerische Zeitschrift für Religions- und Kulturgeschichte 100 (2006): 363-379.

Vinck, Honoré. "Gustaav Hulstaert.” In Biographie Belge d'Outre-Mer Belgische Overzeese Biografie, vol. 8, edited by Académie Royale Science d'Outre-Mer, col. 159-160. Brussels: Librairie Falk fils, 1998.

Vinck, Honoré. "In memoriam Antoon Rubbens." Annales Aequatoria 22 (2001): 440-442. Vleugels, An. Narratives of Drunkenness, Belgium 1830-1914. London: Routledge, 2015. Vogel, Berthold. Die Staatsbedürftigkeit der Gesellschaft. Hamburg: Hamburger Edition, 2007. Vonderau, Asta. "Enterprising self. Neue soziale Differenzierung und kulturelle Selbstdeutungen der Wirtschaftselite in Litauen." In European Economic Elites. Between a New Spirit of Capitalism and the Erosion of State Socialism, edited by Friederike Sattler and Christoph Boyer, 449-469. Berlin: Duncker \& Homblot, 2009.

Waldburger, Daniel. "House, Home, Health and Hygiene-Social Engineering of Workers in Elisabethville/Lubumbashi (1940s to 1960s)." In The Politics of Housing in (Post-) Colonial Africa. Accommodating workers and urban residents, edited by Kirsten Rüther, Martina Barker-Ciganikova, Daniela Waldburger and Carl-Philipp Bodenstein, 141-166. Berlin: De Gruyter, 2020.

Walgenbach, Katharina. "Die weiße Frau als Trägerin deutscher Kultur." Koloniale Diskurse über Geschlecht, "Rasse” und Klasse im Kaiserreich. Frankfurt am Main: Campus 2005.

Watenpaugh, Keith David. Being Modern in the Middle East. Revolution, Nationalism, Colonialism, and the Arab Middle Class. Princeton: Princeton University Press, 2006.

Weisbrod, Bernd. "Medien als symbolische Form der Massengesellschaft. Die medialen Bedingungen von Öffentlichkeit im 20. Jahrhundert." Historische Anthropologie 9 (2001): $270-283$.

Weiss, Herbert F. "L'évolution des élites. Comparaison entre la situation en Afrique occidentale." Etudes Congolaises 5 (1965): 1-14.

Weiss, Herbert F., and Benoît Verhaegen. Parti solidaire africain (P.S.A.), documents 1959-1960. Brussels: Centre de Recherche et d'Information Socio-Politiques, 1963.

West, Michael O. “'Equal Rights for all Civilized Men’: Elite Africans and the Quest for 'European' Liquor in Colonial Zimbabwe, 1924-1961.” International Review of Social History 37 (1992): 376-397. 
West, Michael O. "Liquor and Libido: 'Joint Drinking' and the Politics of Sexual Control in Colonial Zimbabwe, 1920s-1950s.” Journal of Social History 30, no. 3 (1997): 645-667.

West, Michael 0. The Rise of an African Middle Class in Colonial Zimbabwe, 1898-1965. Bloomington: Indiana University Press, 2002.

West, Michael 0. "The African Middle Class in Zimbabwe. Historical and Contemporary Perspectives." In The Making of the Middle Class. Toward a Transnational History, edited by Ricardo A. López and Barbara Weinstein, 45-57. Durham: Duke University Press, 2012.

Wheeler, Douglas L. "Origins of African Nationalism in Angola. Assimilado Protest Writings 1859-1929." In Protest and Resistance in Angola and Brazil. Comparative Studies, edited by Ronald H. Chilcote, 67-87. Berkeley: University of California Press, 1972.

White, Luise S., Stephan F. Miescher and David William Cohen, eds. African Words, African Voices: Critical Practices in Oral History. Bloomington: Indiana University Press.

Wietschorke, Jens. Arbeiterfreunde. Soziale Mission im dunklen Berlin 1911-1933. Frankfurt am Main: Campus, 2013.

Wietschorke, Jens. "Historische Forschung in der Europäischen Ethnologie. Ein Diskussionsbeitrag.” In Kultur_Kultur: Denken. Forschen. Darstellen, edited by Reinhard Johler, Christian Marchetti, Bernhard Tschofen, and Carmen Weith, 206-212. Göttingen: Waxmann, 2013.

Wirz, Albert. "Einleitung: Körper, Raum und Zeit der Herrschaft.” In "Alles unter Kontrolle." Disziplinierungsprozesse im kolonialen Tansania (1850-1960), edited by Albert Wirz, Katrin Bromber, and Andreas Eckert, 5-34. Cologne: Köppe 2003.

Wirz, Albert. Krieg in Afrika. Die nachkolonialen Konflikte in Nigeria, Sudan, Tschad und Kongo. Stuttgart: Franz Steiner, 1982.

Woodson, Dorothy C. Drum. An Index to “Africa's Leading Magazine” 1951-1965. Wisconsin: University of Wisconsin-Madison, 1988.

Yates, Barbara. "Church, State and Education in Belgian Congo." In Women's Education in the Third World: Comparative Perspectives, edited by Gail P. Kelly and Carolyn. M. Elliott, 127-151. Albany: Suny Press 1983.

Young, Crawford. "Imperial Endings and Small States: Disorderly Decolonization for the Netherlands, Belgium, and Portugal." In The Ends of European Colonial Empires. Cases and Comparisons, edited by Miguel Bandeira Jéronimo and António Costa Pinto, 101-125. London: Palgrave Macmillan, 2015.

Young, Crawford. Politics in the Congo. Decolonization and Independence. New Jersey: Princeton University Press, 1965.

Young, Crawford. The African Colonial State in Comparative Perspective. New Haven: Yale University Press, 1997.

Zachernuk, Philip S. Colonial Subjects. An African Intelligentsia and Atlantic Ideas. Charlottesville: University of Virginia Press, 2000.

Zamenga, Batukezanga. Les hauts et les bas. Kinshasa: Médiaspaul, 1971.

Zeilig, Léo. Lumumba: Africa's Lost Leader. London: Haus, 1998.

Zessin, Philipp. Die Stimme der Entmündigten: Geschichte des indigenen Journalismus im kolonialen Algerien. Frankfurt am Main: Campus, 2012. 


\section{Articles in Periodicals}

Arbo, Bertinertin. "Au seuil du championnat 1952 de l'ARSC." Croix du Congo (24 February 1952).

Bolamba, Antoine-Roger. “Activité des cercles, Stanleyville.” Voix du Congolais no. 45 (December 1949): $485-486$.

Bolamba, Antoine-Roger. "A propos des Internats pour des enfants Congolais." Voix $d u$ Congolais no. 60 (March 1951): 129-130.

Bolamba, Antoine-Roger. “A quoi nous sert ce document?” Voix du Congolais no. 64 (July 1951): $351-352$.

Bolamba, Antoine-Roger. “Assimilation.” Voix du Congolais no. 55 (October 1950): 573.

Bolamba, Antoine-Roger. "Bilan de quatre années d'effort." Voix du Congolais no. 33 (December 1948): 487-490.

Bolamba, Antoine-Roger. "Carte du mérite civique. Symbole de devoirs." Voix du Congolais no. 30 (September 1948): 359-362.

Bolamba, Antoine-Roger. "Concours de Propagande." Voix du Congolais no. 24 (March 1948): 121-122.

Bolamba, Antoine-Roger. “Erreur politique?” Voix du Congolais no. 21 (December 1947): $893-894$.

Bolamba, Antoine-Roger. "Hommage à Monsieur le Gouverneur Général Pétillon.” Voix $d u$ Congolais no. 70 (January 1952): 6-8.

Bolamba, Antoine-Roger. “Il faudrait s'entendre.” Voix du Congolais no. 32 (November 1948): 447-449.

Bolamba, Antoine-Roger. "Important discours prononcé par M. Antoine-Roger Bolamba au congrès de Coquilhatville." Indépendance (30 April 1960).

Bolamba, Antoine-Roger. "La communication de M. le Gouverneur Général." Voix du Congolais no. 87 (June 1953): 371-373.

Bolamba, Antoine-Roger. "La députation permanente et l'assimilation des autochtones." Voix du Congolais no. 60 (March 1951): 115-116.

Bolamba, Antoine-Roger. "La politique indigène d'après guerre." Voix du Congolais no. 8 (March-April 1946): 298-300.

Bolamba, Antoine-Roger. "La position sociale des évolués.” Voix du Congolais no. 29 (August 1948): $319-321$.

Bolamba, Antoine-Roger. "La presse européenne et les Congolais." Voix du Congolais no. 57 (December 1950): 693-694.

Bolamba, Antoine-Roger. “L’Elite Noire.” Voix du Congolais no. 44 (November 1949): 416- 417.

Bolamba, Antoine-Roger. “Le problème des Évolués.” Voix du Congolais no. 16 (July 1947): $684-687$.

Bolamba, Antoine-Roger. "Le singe de caméléon.” Brousse no. 3-4 (1947): 28-33.

Bolamba, Antoine-Roger. "Les cercles des évolués.” Voix du Congolais no. 17 (August 1947): $718-720$.

Bolamba, Antoine-Roger. “Le Statut des Évolués.” Voix du Congolais no. 19 (October 1947): 801-803.

Bolamba, Antoine-Roger. "Lettres anonymes et faux rapports." Voix du Congolais no. 15 (May-June 1947): 635-636. 
Bolamba, Antoine-Roger. "Monsieur Pierre Wigny, Ministre des Colonies de Belgique accorde un entretien à une délégation des Évolués de Léopoldville." Voix du Congolais no. 18 (September 1947): 766-767.

Bolamba, Antoine-Roger. “Monsieur Sand, Secrétaire Général.” Voix du Congolais no. 70 (January 1952): 8.

Bolamba, Antoine-Roger. "Note de la rédaction." Voix du Congolais no. 49 (April 1950): 242. Bolamba, Antoine-Roger. "Opportunité de créer un statut pour les évolués." Voix du Congolais no. 3 (May-June 1945): $72-81$.

Bolamba, Antoine-Roger. “Prudence oblige.” Voix du Congolais no. 39 (June 1949): 219-220. Bolamba, Antoine-Roger. "Réflexion.” Voix du Congolais no. 72 (March 1952): 127.

Bolamba, Antoine-Roger. "Silhouette Indigène." Croix du Congo (4 February 1945).

Bolamba, Antoine-Roger. "Souvenirs d'un grand chef." Voix du Congolais no. 14 (March-April 1947): 603-605.

Bolamba, Antoine-Roger. "Une année historique." Voix du Congolais no. 7, January-February 1946): $242-244$.

Bolamba, Anoine-Roger. “Une caisse d’Epargne Congolaise.” Voix du Congolais no. 51 (June 1950): 323-324.

Bolamba, Antoine-Roger. "Un fils qui voulait être plus malin que son père." Brousse no. 3-4 (1949): 25-26.

Bolamba, Antoine-Roger. "Une politique de pleine intégration." Voix du Congolais no. 82 (January 1953): 3.

Bolamba, Antoine-Roger. "Vie, coutume et mœurs des Mongo de l’Équateur.” Voix du Congolais no. 145 (April 1958): 195-300.

Bolikango, Jean. "Qu'est-ce qu’un Adapessiens." Croix du Congo (8 June 1952).

Bolya, Paul. "Cercle d'étude et d'agrément." Voix du Congolais no. 75 (June 1952): 369-371.

Bongongo, Léon. “Pourqoui pas moi?” Voix du Congolais no. 56 (November 1950): 650-653.

Chirishungu, E. B. “Au tableau d'honneur de l'elite.” Voix du Congolais no. 74 (May 1952): 301-303.

Clément, Pierre. “Patrice Lumumba (Stanleyville 1952-1953).” Présence Africaine no. 40 (1962): $57-78$.

Colin, Michel. "La femme africaine face au monde moderne." Voix du Congolais no. 145 (April 1957): $274-275$.

Colin, Michel. “L’allégresse du fair play sportif." Voix du Congolais no. 73 (April 1952): $214-216$.

Colin, Michel. “L’art de lire.” Voix du Congolais no. 75 (June 1952): 339-344.

Colin, Michel. "Noces d'or." Voix du Congolais no. 95 (February 1954): 145-147.

Comité de l'A.P.I.C. "Au tableau d'honneur de l'elite noire remise des Cartes de mérite civique." Voix du Congolais no. 48 (March 1950): 163-164.

Davier, Joseph. "Femme au volant." Voix du Congolais no. 108 (March 1955): 305-307.

Davier, Joseph. "Souvenirs d'anniversaire." Voix du Congolais no. 106 (January 1955): 6-16.

Decoux, A. “Avis du Public.” Voix du Congolais no. 79 (October 1952): 597.

Dericoyard, Jean-Pierre. "A propos du problème de l'assimilation des congolais." Voix $d u$ Congolais no. 55 (October 1950): 576-578.

Dubuka, Jean-Pierre. "Le Blanc ignore encore l'âme du Noir et la provenance de sa pauvreté." Voix du Congolais no. 22 (January 1948): 14-15.

Elima. "Daring écrase Dragons et accentue son avance." Croix du Congo (23 March 1952). 
Embae, Louis. “Il y a 'évolués' et 'évolués'.” Voix du Congolais no. 19 (October 1947): $816-818$.

Ephémérides. "Le décès de M. Emmanuel Capelle." Voix du Congolais no. 91 (October 1953): 697-698.

F. M. “Les oeuvres post-scolaires de Léo II." Signum Fidei (August-September 1936): $254-256$.

Godding, Robert. "La politique indigène du Congo Belge." Croix du Congo (16 January 1944). Howlett, Jacques. “La Revue des Revues.” Présence Africaine no. 1 (1947): 179.

Kagame, Alexis. "L’évolué réel de l’Afrique Belge.” Voix du Congolais no. 9 (May-June 1946): $356-359$.

Kandé, Jean-Jacques. "Elle donne le ton à la mode.” Quinze (July 1957).

Kandé, Jean-Jacques. "Fumeries de chanvres." Quinze (16 August 1957): 3-7.

Kangudie, Pierre. "La véritable évolution doit être spirituelle et non seulement matérielle." Voix du Congolais no. 52 (July 1950): 413-414.

Kanza, E. Rodolphe Thomas. “Adieu Matriarchat!” Voix du Congolais no. 75 (June 1952): $345-347$.

Katoto, Hilaire-Daniel. "L'habit ne fait pas le moine." Voix du Congolais no. 18 (September 1947): 761-762.

Kilembi, André. Kilembi, “Joie et tristesse.” Voix du Congolais no. 23 (February 1948): 69-70.

Kingansi, Léon. “A beau mentir vient de loin.” Voix du Congolais no. 63 (June 1951): $318-320$.

Koy. "Sango na Yahuma." Voix du Congolais no. 139 (October 1957): 6-9.

Lammerant, Yvonne. "La femme congolaise et son évolution." La femme et le Congo no. 162 (July 1958): 6-9.

Landu, Michel. "Sachons gérer notre avoir." Voix du Congolais no. 72 (March 1952): $146-149$.

Le Comité. “Le Mouvement National Congolais est né." Présence Congolaise (18 October 1958).

Levent, George Kimbangui. "Pourquoi ne pas le dire.” Voix du Congolais no. 53 (August 1950): $476-478$.

Lomami-Tshibamba, Paul. "Les devoirs des évolués." Voix du Congolais no. 4 (July-August 1945): $114-121$.

Lomami-Tshibamba, Paul. “Les devoirs des évolués.” Voix du Congolais no. 4 (July-August 1945): $169-173$.

Lomami-Tshibamba, Paul. "Quelle sera notre place dans le monde de demain," Voix du Congolais no. 2 (March-April 1945).

Lomboto, Joseph. "Pour un peu de mesure." Voix du Congolais no. 34 (January 1949): 18-19.

Lukunku, François. “A Monsieur Jean Bolikango.” Indépendance (30 April 1960).

Lumumba, Patrice. “Activité des cercles, Stanleyville.” Voix du Congolais no. 71 (February 1952): 110.

Lumumba, Patrice. "A propos l'accès des Congolais dans les établissements publics pour Européens." Voix du Congolais no. 115 (October 1955): 803-806.

Lumumba, Patrice. "La question des 'étrangers'." Croix du Congo (18 March 1951).

Lumumba, Patrice. “Nouvelles de l’ADAPES Stanleyville.” Croix du Congo (14 February 1954). 
Lumumba, Patrice. "Quand on se connait soi-même, que reste-il à faire?” Croix du Congo (19 November 1950).

Lumumba, Patrice. “Un explorateur incomparable.” Voix du Congolais no. 100 (July 1954): $516-522$.

Mahutama, Georges. "Pour la carte des Évolués.” Voix du Congolais no. 25 (April 1948): 157.

Maks. "Une carte d'interlocuteur valable, s.v.p. Je désire être consulté." Présence Congolaise (11 October 1958).

Mbaya, Pierre. "Fréquentez votre cercle culturel." Croix du Congo (13 July 1952).

Mobé, Antoine-Marie. "A propos des devoirs des évolués.” Voix du Congolais no. 34 (January 1949): $12-15$.

Mobé, Antoine-Marie. "A qui faut-il octroyer la carte du Mérite Civique.” Voix du Congolais no. 46 (January 1950): 16-22.

Mobé, Antoine-Marie. "Beaucoup d'argent gâte les noirs," Voix du Congolais no. 55 (October 1950): $582-583$.

Mobé, Antoine-Marie. “Chronique de la vie indigène et nouvelles diverses." Voix du Congolais no. 20 (October 1947): 877.

Mobé, Antoine-Marie. "Du rôle véritable des Associations d'Evoluants." Voix du Congolais no. 88 (July 1953): $470-471$.

Mobé, Antoine-Marie. "Echos de Stanleyville." Croix du Congo (4 March 1951).

Mobé, Antoine-Marie. "Encore un mot au sujet de la Carte du Mérite Civique." Voix du Congolais no. 60 (March 1951): 122-124.

Mobé, Antoine-Marie. "Entente dans les cercles dits d’Évolués." Croix du Congo (25 June 1950).

Mobé, Antoine-Marie. "La fidelité à la parole donnée." Voix du Congolais no. 48 (March 1950): $144-148$.

Mobé, Antoine-Marie. "Nécessité des Associations Indigènes." Voix du Congolais no. 33 (October 1948): 497-500.

Mobé, Antoine-Marie. "Réfutation." Voix du Congolais no. 29 (August 1948): 330.

Mongita, Albert. “Ce que j'ai vu sur le Lokele bâtiment flottant de l'Otraco." Voix du Congolais no. 115 (October 1955): 831-834.

Moukeba, J. D. “Economie et Gaspillage.” Voix du Congolais no. 53 (August 1950): 458-462.

Mpako, Norbert. “Une opinion,” Voix du Congolais no. 142 (January 1958): 79-80.

Mujinga, Ruffin-Pierre. “Indemnités familiales et ... polygamie 'camouflée'.” Voix du Congolais no. 48 (March 1950): 152-154.

Mujinga, Ruffin-Pierre. “La voix de la raison.” Voix du Congolais no. 36 (March 1949): $110-111$.

Mupenda, Jérôme-Ernest. “L’Évolué est-il maladroit?” Voix du Congolais no. 27 (June 1948): $236-237$.

Mutombo, Nestor. “Comment élever nos enfants.” Voix du Congolais no. 60 (March 1951): $131-132$.

Mwissa, Camus. "Horizons." Croix du Congo (29 December 1957).

Ngandu, Etienne. "Ce qui dit le Noir chez-lui.” Voix du Congolais no. 8 (March-April 1948): $314-315$.

Ngandu, Etienne. “Civisme ou esprit social.” Voix du Congolais no. 32 (November 1948): $450-455$. 
Ngandu, Etienne. "Comment se marier." Voix du Congolais no. 11 (September-October 1946):

447- 449 .

Ngandu, Etienne. "Dangers et méfaits de l'alcool.” Voix du Congolais no. 14 (March-April 1947): $592-594$.

Ngandu, Etienne. “La carte d’Évolué est-elle nécessaire.” Voix du Congolais no. 26 (May 1948): $198-201$.

Ngandu, Etienne. “L’Alcoolisme et les maux du buveur." Voix du Congolais no. 52 (July 1950): $390-395$.

Ngandu, Etienne. "L'école instruit mais la famille forme le caractère." Voix du Congolais no. 27 (June 1948): 242-245.

Ngandu, Etienne. "Pierre, si tu veux entrer dans un édifice, laisse-toi tailler." Voix $d u$ Congolais no. 49 (April 1950): 197-200.

Ngeke, Aloïs-Antoine. "La carte du mérite civique scindera-t-elle la classe des évolués?" Voix du Congolais no. 140 (November 1957): 840-842.

Ngwenza, A. "En marge de la fête anuelle de l'ADAPES." Croix du Congo (8 June 1952).

N.n. "Groupement Belgo-Congolais." Le Soir (23 February 1951).

Omari, Antoine. "A propos de la Carte du mérite Civique." Voix du Congolais no. 51 (June 1950): $350-351$.

Omari, Antoine. “Immatriculés ou Fantaisistes?” Actualités Africaines (27 June 1952): 3.

Omari, Antoine. "L’assimilation des Congolais.” Voix du Congolais no. 55 (October 1950): $581-582$.

Omari, Antoine. "Le sort des assimilés." Actualités Africaines (10 January 1957): 3.

Omari, Antoine. "Une excellente nouvelle." Voix du Congolais no. 74 (May 1952): 256-258.

Perken, Claude. “Où va l'Afrique noire?” Quinze no. 5 (August 1957): 12-15.

Piron, Pierre. "L'évolution des populations détribalisés." In Les évolués, VIII. Commission, edited by Congrès Colonial National, 27-71. Brussels: 1947.

Piron, Pierre. "Le problème des assimilés." In Les évolués, VIII. Commission, edited by Congrès Colonial National, 15-26. Brussels: 1947.

Piron, Pierre. “La réforme de l'immatriculation." La Revue coloniale belge 33 (1947): 99-106.

Scohy, André. "Un ordre du mérite civique et professionnel." Croix du Congo (1 October 1945).

Selemani, Jean. "Les évolués et leurs noms." Nyota Etoile (6 March 1947): 2.

Sohier, Antoine. "Le rôle de la femme dans la famille indigène congolaise." Mbandaka (4 October 1947): 1-2.

Songolo, Alphonse. “M. Patrice Lumumba à l'honneur." Voix du Congolais no. 106 (January 1955): $190-191$.

Songolo, Alphone. "Réflexions d'un propagandiste de La Voix du Congolais." Voix du Congolais no. 65 (August 1951): $443-447$.

Varney, A. "Au sujet d'une conférence." Croix du Congo (21 December 1952).

Yage, Bernard. "Cri d'alarme.” Voix du Congolais no. 35 (February 1949): 67-68.

Yembe, Eugène. "Voulons-nous être traités en hommes civilisés?” Voix du Congolais no. 37 (April 1949): 134-135. 